\title{
COMMUNIST FOOTPRINT AND SUBORDINATE INFLUENCE BEHAVIOR IN POST-COMMUNIST TRANSITION ECONOMIES
}

http://dx.doi.org/10.1016/j.jwb.2016.12.002

Available online 13 December 2016

\begin{tabular}{|c|c|c|}
\hline Elitsa R. Banalieva* & e.banalieva@northeastern.edu & Northeastern University, USA \\
\hline Charlotte M. Karam & ck16@aub.edu.lb & American University of Beirut, Lebanon \\
\hline David A. Ralston & dralston@ou.edu & University Fellows International Research Cons \\
\hline Detelin Elenkov & detelin.elenkov@marist.edu & Marist College, USA \\
\hline Irina Naoumova & naoumova@hartford.edu & University of Hartford, USA \\
\hline Marina Dabic & mdabic@efzg.hr & $\begin{array}{l}\text { University of Zagreb, Croatia \& Nottingham } \\
\text { Trent University, Trent University, the UK }\end{array}$ \\
\hline Vojko Potocan & vojko.potocan@uni-mb.si & University of Maribor, Slovenia \\
\hline Arunas Starkus & arunas.starkus@ciber.lt & CIBER-Vilnius, Lithuania \\
\hline Wade Danis & iibwmd@langate.gsu.edu & University of Victoria, Canada \\
\hline Alan Wallace & wallacealan@hotmail.com & Retired, USA \\
\hline
\end{tabular}

Acknowledgements: We are deeply grateful to JWB Senior Editor David Ahlstrom, the two anonymous reviewers, and Imad Bou-Hamad, Paula Caligiuri, Alvaro Cuervo-Cazurra, John Dencker, Thomas Grigglestone, Wit Henisz, Kimberly Eddleston, Aparna Joshi, Harry Lane, Tomasz Lenartowicz, Antonio Majocchi, and Mona Makhija for their insightful feedback that helped improve the quality of our paper.

*Corresponding author. 


\title{
COMMUNIST FOOTPRINT AND SUBORDINATE INFLUENCE BEHAVIOR IN POST-COMMUNIST TRANSITION ECONOMIES
}

\begin{abstract}
How does length of exposure to communism, the communist footprint, affect individuals' influence behaviors at work today? While imprinting theory has debated how exposure/lack thereof to communism - communist imprint - affects individuals, it has disregarded the exposure's length. We show that the shorter the communist footprint, the less negative professionals are toward organizationally constructive influence behaviors, and that individuals with longer communist footprints at higher-level position levels do not approve of organizationally destructive behaviors as much as their lower-level counterparts. We thus show that the continuous communist footprint provides a better understanding of work behaviors today than the dichotomous communist imprint.
\end{abstract}

Keywords: communist footprint; subordinate influence behavior; imprinting theory; fairness heuristic theory; post-communist transition economies 
What patterns of work behavior in today's global economy can managers expect from colleagues who were socialized under communist systems in the former Soviet Union? ${ }^{1}$ To begin, it is relevant to profile the uniqueness of the communist system, as an important episode in the history of the former Soviet Union, with regards to the work behaviors of individuals who were exposed to it and worked under its many conditions and extremes (Applebaum, 2003; Christensen, 1999). Given the oppressive, top-controlled nature of communism (Kornai, 2000; Puffer, 1993, 1994), it was difficult for individuals within a communist system to survive and progress without becoming skillful at utilizing a range of informal influence strategies as the political elite suppressed overt personal aspirations and formal effort to achieve them as well as limiting more conventional motivational attempts to get organizational work done (Danis, Liu, and Vicek, 2011). Thus, a secret for survival and progress in the communist system was the skill subordinates had in employing informal influence tactics with their superiors that could range from organizationally constructive (pro-organizational and image management) to organizationally destructive (self-serving and maliciously intended) (Cialdini, 2006; Podsakoff et al., 2000; Ralston et al., 2009). Increasingly, research points "to the importance of taking account of what was left behind by communism" (Pop-Eleches and Tucker, 2014: 77) and learning from important prior episodes in history for a more holistic understanding of how history affects human behavior (Ahlstrom, 2014; Hunter, 2013; Peng, 2013), and how researchers can understand it better and include it in their work (Cooke, 2003; Peng, Ahlstrom, Carraher, \& Shi, 2017). Hence, it is useful to analyze how individuals who were socialized during the communist era in Eastern Europe try to affect the patterns of work behavior that their managers expect from them at work today.

It is important to understand the impact that these informal influence strategies have in the workplace because, in our increasingly globalizing economy, it has become commonplace to work with colleagues who were once raised under communism in the post-communist transition economies in Central and South-Eastern Europe, or some other significantly different political-economic system. They could be colleagues who were just children or adults when the Berlin Wall fell, for example. Going beyond the basic question of how such communist-socialized professionals are likely to behave

\footnotetext{
${ }^{1} \mathrm{We}$ use the terms communism and socialism interchangeably in this paper, in line with prior research (e.g., Johnson, Kaufmann, McMillan, and Woodruff, 2000; Kornai, 2000).
} 
at work today, the more intriguing question becomes, will they behave similarly owing to their long exposure to communism and what do those similar behaviors include? Existing research, drawing from imprinting theory, implicitly assumes so (e.g., Danis et al., 2011). Imprinting theory suggests that entities are stamped by the external environment in which they came into existence and carry this imprint forward in life (Stinchcombe, 1965). This research proposes that communist-socialized adults did not inherit a tabula rasa after communism's collapse but transitioned into the new market reality with a repertoire of communist-acquired experiences that their non-communist socialized colleagues did not inherit.

While imprinting theory has focused on the presence or absence of exposure to environments that leave imprints (Simsek, Heavy, and Fox, 2015), seldom has the heterogeneous length of exposure to such environments been examined for its effect (cf. Vogel, 1972). In the context of communism, imprinting theory has not yet considered that communist-socialized individuals had been exposed to communism for varying lengths of time, as some experienced the communist indoctrination longer than others. The question then becomes do all of these communist-socialized colleagues perceive in the same way the acceptability of different influence behaviors at work today, regardless of their varying lengths of prior communist exposure? Addressing this question is crucial for any manager working with communist-socialized subordinates as it has implications for motivating, communicating, negotiating, and collaborating with these employees (Caprar and Budean, 2013; Danis et al., 2011; Falbe and Yukl, 1992; Fu and Yukl, 2000) as well as for navigating the challenging environment in transition economies (Ahlstrom, Young, Nair, and Law, 2003; Mutlu, Zhan, Peng, and Lin, 2015).

Research laments that we still know little about how communist socialization affects professionals' current work behavior (Alas and Rees, 2006). Existing findings have also been inconclusive. Some studies have suggested that communism has conditioned people to be more cynical and mistrustful of authority and, thus, more focused on protecting their self-interests first (Pop-Eleches and Tucker, 2014; Uslaner and Badescu 2004). Others have countered that communist hardships inspired people to want to personally contribute their best to their organizations after the onset of market liberalization (Hurt, Hurt-Warski, and Roux-Dufort, 2000). Still others have found 
that the presence or absence of the prior communist socialization, ultimately had no significant effect on professionals' current perceptions of the acceptability of influence behaviors at work (Danis et al., 2011).

We clarify this debate in two ways. First, we propose that the answer depends on the professional's length of exposure to communism - the communist footprint. This continuous construct draws from fairness heuristic theory (van den Bos, Vermunt, and Wilke, 1997a, b) to capture the varying intensities of fairness judgments about communist authority that individuals formed depending on how short or prolonged their communist socializations were. Traditional fairness heuristic theory proposes that individuals form fairness judgments during their interactions with authority, and that judgments about earlier experiences with unjust authority carry more weight (van den Bos et al., 1997a, b). As such, the communist footprint extends imprinting theory's current focus on the presence or absence of an ideological stamp from the external environment (Danis et al., 2011; Simsek et al., 2015; Stinchcombe, 1965). So far, international management studies have not analyzed how the length of communist exposure, or the length of exposure to a specific episode in a country's history (i.e., communism in our case) (Ahlstrom, 2014; Hunter, 2013; Peng, 2013), affects influence behaviors at work today. In contrast, we proposed and found that the shorter the communist footprint, the less negative professionals are toward organizationally constructive influence behavior at work today, holding all else constant, owing to these individuals' shorter experience with fending for themselves during communism. We further proposed and found that individuals with longer communist footprints at higher-level positions in their organization did not approve of organizationally destructive behaviors to the degree that individuals at lower-level positions did, owing to the former's higher sense of paternalistic responsibility toward their subordinates and organizations.

Hence, our first intended theoretical contribution is to extend the existing discrete perspective of imprinting theory with a new, process approach that explicitly integrates the effect of an individual's length of exposure to communism through the concept of the communist footprint. Specifically, we suggest that the communist footprint has a direct effect on influence behaviors at work today. The length of exposure time is a core component of any process, as it seeks to link past 
experiences with current behavior (Coraiola, Foster, and Suddaby, 2015; Lane, 2014; Pop-Eleches and Tucker, 2014). A process perspective allows differentiating between different intensities of communist indoctrination based on the length of the communist footprint. Similar to developing a photograph in a chemical solution, a longer communist footprint reflects, by definition, a stronger intensity of communist indoctrination. Conversely, the shorter the photograph stays exposed to the chemical solution, the less intense the image becomes, reflecting a weaker intensity of indoctrination into the communist system and its mores.

Second, we further extend imprinting theory by answering recent calls in the literature for a more nuanced understanding of whether initial imprints are weaker for some individuals than for others (Simsek et al., 2015), and if so, under what conditions. We take this call for research a step further and analyze whether the communist footprint is stronger for some individuals than for others, and if so, under what contextual conditions. By contextual conditions we mean "situational opportunities for, and countervailing constraints against, organizational behavior" (Johns, 2006: 387). We thus analyze how contextual variables may modify the relationship between the communist footprint and influence behaviors employed by the former employees under the communist system Recent extensions to fairness heuristic theory have noted that fairness judgments can be weaker under some contextual conditions than under others. This is because ethical decision-making depends on individual factors, situational factors (Bobocel, 2013; Jones and Starlicki, 2013; Kuratko and Goldsby, 2004), and their interplay as "memory interacts with present circumstances" to further shape human behavior (Fortin et al., 2014: 14). The key individual factor in our study is the individual's communist footprint. A key contextual condition for any working individual is their position level in the company: lower-level positions (non-supervisory staff and first-level managers) or higher-level positions (middle- and upper-level managers) (Ahearne, Lam, and Kraus, 2014; Fields, 2002; Neugeboren, 1991; Ralston et al., 2013). Different organizational levels present different “organizational requirements" (Neugeboren, 1991: 147) and, similar to other contextual variables, position works to restrict the observed range of salient organizational factors and to shape the base rates of key organizational variables over time (Johns, 2006). Since lower vs. higher-level positions carry different roles and expectations as well as access to different contextual realities for the 
professionals occupying them, they are likely to further modify the communist footprint-influence behaviors baseline relationships (Chen, 2014; Trevino et al., 2008). As such, the moderating effect of organizational position on the communist footprint-influence behaviors relationships-provides a nuanced perspective on the strength of accumulated fairness judgments from prior communist socialization. Indeed, viewing position as a contextual variable directs our attention to better exploring multilevel relationships such as the cross-level moderating relationship of position on lower-level relationships (see Kozlowski and Klein, 2000).

\section{CONCEPTUAL BACKGROUND}

\section{Subordinate Influence Behavior and the Communist Imprint}

Subordinate influence behavior concerns how subordinates can use different forms of upward influence to obtain desired outcomes from their superiors (Caprar and Budean, 2013). These behaviors range from softer forms of influence that are organizationally constructive (e.g., maintain good working relationships) to the harder forms of influence that are organizationally destructive (e.g., steal secret corporate documents to extort the company) (Podsakoff et al., 2000).

Existing upward influence behavior research has studied dispositional (e.g., individual traits, internal/external locus of control, values, or communist imprint, Danis et al., 2011; Ralston et al., 2013), situational (e.g., organizational culture, economic or socio-cultural development, Karam et al., 2013; Ralston et al., 2009), and demographic (e.g., gender, education, age, and religious beliefs, Linz and Chu, 2013) factors as key drivers of such behavior (for an overview, see Dulebohn et al., 2012; Ralston and Pearson, 2010). With some notable cross-country exceptions (e.g., Caprar and Budean, 2013; Egri et al., 2000; Fu and Yukl, 2000; Karam et al., 2013; Ralston et al., 2009, 2013; Ralston and Pearson, 2010), most subordinate influence studies have explored these antecedents in singlecountry—mostly U.S.—samples. The relevant cross-cultural research has shown that firm characteristics (Karam et al., 2013; Ralston et al., 2009) and countries' current institutional development and values (Egri et al., 2000; Karam et al., 2013; Ralston et al., 2009, 2013) can affect current subordinate influence behavior.

Despite these important advances, "surprisingly little" remains known about how individuals" prior communist socialization affects their current perceptions of acceptable work behaviors today 
(Alas and Rees, 2006: 183). Only recently has international management research begun exploring how the types of prior institutions in one's home country affect one's current subordinate influence behavior at work in a post-communist transition economy context (Danis et al., 2011). Postcommunist transition economies include the states of Central and Southeastern Europe that were once communist but underwent a dramatic shift from Soviet-style central planning to capitalist-style market liberalization in the early 1990s (Hoskisson, Eden, Lau, and Wright, 2000; Hoskisson, Johnson, Tihanyi, and White, 2005). Danis et al. (2011) studied how the presence or absence of a communist imprint affects upward influence behaviors of Czech subordinates. They found that, ultimately, the communist imprint had no significant effect on the subordinates' influence behaviors today.

As noted, what remains unclear is how the length of the communist socialization - the communist footprint — affects subordinates' current perceptions of acceptable influence behaviors and whether there are situational factors that further modify this relationship. To address these questions, we next draw insights from fairness heuristic theory (van den Bos et al., 1997a, b), which we later integrate with imprinting theory to form the basis of our theoretical framework.

\section{The Communist Legacy and Fairness Heuristics of Individual Behavior}

During communism, state control permeated every aspect of individual life in an attempt to achieve full subordination of the individual to the state's ideal of the Soviet Man. This was "a Leninist ideal of a perfect citizen, perfect man, and perfect communist" (Tverdohleb, 2012: 365, 370). Socially, the state assigned local representatives to micromanage individuals by keeping a watchful eye on deviations from state-sanctioned behaviors of perfect morale (Fitzpatrick, 1999). Even small deviations triggered ad-hoc punishments. The regime further pitted people against each other and encouraged people to report on each other to the authorities (Applebaum, 2003; Uslaner and Badescu, 2004). Economically, the state limited foreign imports and consumer goods, redirecting the economy toward industrial products (Napier and Thomas, 2004). Severe food shortages ensued and people had to learn how to survive; they navigated the system as 'socialist entrepreneurs' (Szelenyi, 1988). The state retained an active role in allocating resources for supply and production, yet demanded rapid development through five-year plans. This forced communist-socialized professionals to continually be in search of ways to seek connections to obtain the resources needed to avoid falling behind state 
orders (McCarthy and Puffer, 2008; Puffer and McCarthy, 2003). Working conditions were poor as employees neither had an "exit option" to find sustainable alternatives, nor a "voice option" to form free trade unions without interference from government fiat (Blanchflower and Freeman, 1997: 440).

The above socio-economic challenges of life under communism forced communist-socialized individuals to be vigilant and mistrustful, resenting the state's pervasive authority over their lives. This is consistent with the predictions of fairness heuristic theory (van den Bos et al., 1997a, b), which suggests that individuals use cognitive shortcuts (heuristics) to infer how trustworthy authority is and, hence, to decide whether to engage in organizational-oriented or self-oriented behaviors. According to the theory, individuals form their cognitive shortcuts based on prior repeated experiences (e.g., growing up under the communist authority). As such, fairness heuristic theory notes that an earlier life-stage interaction with authority such as communism has a more profound effect on individuals than a later life-stage interaction such as market liberalization (van den Bos et al., 1997a, b). As a result, fairness heuristic theory posits that individuals form perceptions of fairness from continually dealing with such authority that solidify into expectations about how likely the individuals are to get fair treatment from authority in the future (Jones and Skarlicki, 2012).

\section{A PROCESS PERSPECTIVE ON SUBORDINATE INFLUENCE BEHAVIOR IN POST-COMMUNIST TRANSITION ECONOMIES}

\section{Extending Imprinting Theory}

We extend imprinting theory (Simsek et al., 2015) in two ways. First, we propose that when imprinting is applied to research on human behavior, the more relevant focus becomes the individual's socialization process beyond the initial imprint, which is captured by the communist footprint. Second, using recent fairness heuristic insights that initially accumulated fairness judgments can be stronger or weaker for some individuals than others depending on context (Fortin et al., 2014), we propose that the individual's position level in the company further modifies the relationship between the communist footprint and influence behaviors at work today. We elaborate on these two theoretical extensions next. 
An individual's communist footprint. Figure 1 illustrates the conceptual distinction that we draw between the communist imprint and footprint. Panel A shows the literature's current discrete conceptualization of the communist imprint. It exists for individuals socialized during communism, and it does not for individuals born and socialized during market liberalization (e.g., Danis et al., 2011). Panel B shows our proposed continuous conceptualization of the communist footprint. It ranges from longer (for individuals born far before the start of market liberalization) to shorter (for individuals born closer to the start of market liberalization). As such, the communist footprint allows for a much more nuanced theorizing that accounts for the actual length of exposure to communist indoctrination and the corresponding degree of accumulated negative judgments about the communist authority.

\section{[FIGURE 1 HERE]}

Based on traditional fairness heuristic arguments, a longer communist footprint would scar an individual with longer lasting anti-authority judgments (van den Bos et al., 1997a, b). Socialization and identity research confirms that an individual's identity is formed during such pre-adult socialization (Mannheim, 1952). During this time, the individual processes different worldviews and values (Dekas and Baker, 2014). Once internalized, they "tend to remain fairly stable across the lifespan and guide behavior across a wide variety of situations" (Dekas and Baker, 2014: 55-56). With other factors held constant, the longer the communist footprint, the more the individual has grown to believe that it is fair to seek one's own benefit first before everyone else's in order to be compensated for his/her prolonged unfair treatment under communism in the past. Conversely, a shorter communist footprint occurs when a communist-socialized individual experiences pro-market reforms - policies that shift the country's development from a communist to a capitalist trajectory (Chari and Banalieva, 2015) — earlier in his/her socialization. Such individuals would learn the new market-based principles of fair competition, initiative-taking, and acceptable work practices earlier in their lives and, hence, would likely have accumulated less negative judgments against authority today (Linz and Chu, 2013).

Situational context: the modifying role of position level in company. We further extend imprinting theory by drawing insights from more recent advances in fairness heuristic theory. Specifically, recent research has noted that initial fairness judgments can be weaker for some 
individuals than others, because ethical decision-making depends on individual factors, situational factors, and their interplay (Bobocel, 2013; Jones and Starlicki, 2013; Fortin et al., 2014; Kuratko and Goldsby, 2004). Indeed, international management studies show that the social context curtails the influence of demographic factors and disciplines the individual to assume appropriate roles and meet the expectations for these roles (Chen, 2014; Dutton et al., 1997; Trevino et al., 2008).

An important situational context for any working individual is their position in the company: lower-level positions (non-supervisory staff and first-level managers) or higher-level positions (middle- and upper-level managers) (Ahearne et al., 2014). Position level is a broad situational factor in line with prior research (e.g., Fields, 2002; Neugeboren, 1991; Peter and O'Connor, 1980). For instance, Fields (2002: 2) notes that "a broad situational factor, job level, is positively correlated with satisfaction..." Neugeboren (1991: 147) adds that different organizational levels present different "situational requirements." Our focus on the position level in the company is aligned with calls for a focus on contextual conditions in the study of employee behaviors (Johns, 2006; Kozlowski \& Klein, 2000) and with management scholars who have long argued that context serves as a set of forces setting the parameters (opportunities/constraints) for employee behavior (Lewin, 1951; Mowday \& Sutton, 1993; Rousseau \& Fried, 2001). Since different positions carry different expectations from professionals, position level in the company affects employees' judgments and is likely to further modify the communist footprint-influence behaviors baseline relationships (Chen, 2014; Trevino et al., 2008).

We next develop our theoretical framework. We focus on two orthogonal types of influence behavior at work: organizationally constructive and organizationally destructive. Organizationally constructive influence behavior is the softer/nicer influence type that puts the interests of the organization at least at par with, if not ahead of, the interests of the individual (Podsakoff et al., 2000). Conversely, organizationally destructive influence behavior is the harder/nastier type that always puts the interests of the individual ahead of those of the organization (Ralston et al., 2013). We first present the baseline effects of communist footprint on the organizationally constructive and destructive behaviors, holding other factors constant $(\mathrm{H} 1 \mathrm{a}-\mathrm{H} 2 \mathrm{~b})$. We then present how the 
individual's social context (i.e., position level in the company) moderates these baseline effects (H3a$\mathrm{H} 4 \mathrm{~b})$.

\section{Subordinate Communist Footprint and Organizationally Constructive Influence Behavior}

We study two core types of organizationally constructive influence behavior: proorganizational and image management (Ralston et al., 2009).

Pro-organizational behavior. Pro-organizational behavior is an ideal form of approved employee behavior in organizations. It tends to be directly beneficial to the organization regardless of whether it benefits the individual or not, akin to organizational citizenship behavior (Podsakoff et al., 2000). An example of a pro-organizational influence behavior is working overtime, if necessary, to get the job done. We propose that, holding other factors constant, the longer the communist footprint, the less the subordinates will perceive pro-organizational influence behavior as acceptable at work today.

First, communism subjugates individuals' interests to those of the state (Napier and Thomas, 2004; Pop-Eleches and Tucker, 2014), leaving little if any room for individual dissent. Thus, a longer communist footprint indicates that the individual has socialized with others who also feel exploited by the state for a longer period of time (Schwartz and Bardi, 1997). Such prolonged communist socialization sustains suspicion and distrust of others (Napier and Thomas, 2004; Pearce, 1991; Uslaner and Badescu, 2004). Under such tight state control, individuals do not believe their superiors will reciprocate the demonstrated good-willed behavior, as these can lead to an increased risk of being exploited (Blanchflower and Freeman, 1997; Schwartz and Bardi, 1997). We expect that the longer an individual has been exposed to the communist indoctrination, the more inculcated the communist footprint becomes (Pop-Eleches and Tucker, 2014), leading the subordinate to discount the value from using pro-organizational behavior.

Conversely, a shorter communist footprint indicates that the subordinates have socialized for longer under the new rules of the game ushered in by market liberalization. Market liberalization marks the fall of communism and inherently makes the work environment more competitive, transparent, and dynamic for everyone (Nadkarni and Barr, 2008). Market liberalization demands a drastic shift in an individual's focus toward efficiency, over-performance, and a strong work ethic 
(Pucetaite and Lamsa, 2008). Individuals with shorter communist footprints have socialized earlier in their lives into accepting as normal that working under such transparent organizational environments requires one to proactively probe ideas that can benefit the organization and be personally accountable for one's actions in order to receive a positive outcome from the organization, such as promotion (Lind and van den Bos, 2002). Such individuals can also more readily embrace these new marketbased practices as a result of having socialized longer with people who also embrace this new paradigm shift. Since the new rules apply to everyone in the organization, a shorter communist footprint would lead individuals to believe that pro-organizational behavior will be not only accepted but also reciprocated in their current organizations.

Second, communism intensified the negative fairness judgments of subordinates toward the ruling elite (Pearce, 1991; van den Bos et al., 1997a, b). A longer communist footprint indicates that the subordinate has grown accustomed to seeing many superiors living above the law, lavishly and without regard for the good of their colleagues (McCarthy and Puffer, 2008). A prolonged experience with such persistent bureaucratic corruption would reduce the value from engaging in proorganizational behavior at work, today, as people harbor accumulated uncertainty and mistrust toward authority figures (van den Bos et al., 1997a, b). Indeed, traditional fairness heuristic theory suggests that a wronged individual would perceive giving control to another as opening the door for further manipulation and mistreatment (van den Bos et al., 1997b). The sarcasm in "they pretend to pay us and we pretend to work" (Tsoukas, 1994: 35) provides anecdotal evidence that supports the derogatory views subordinates held of their superiors. Thus, a longer communist footprint indicates that subordinates have likely been indoctrinated to perceive pro-organizational behavior as imprudent (Lind and van den Bos, 2002).

Conversely, a shorter communist footprint indicates that the subordinates are less likely to harbor such negative perceptions of their superiors today. Encountering market liberalization earlier in life socializes people earlier into capitalist management practices that predispose subordinates to be more positive toward their employer (Pucetaite and Lamsa, 2008). In line with traditional fairness heuristic theory (Lind and van den Bos, 2002), a shorter communist footprint increases subordinates' 
confidence in being rewarded for their pro-organizational efforts. Thus, we propose that holding other factors constant:

H1a: In post-communist transition economies, the longer the communist footprint, the less acceptable subordinates perceive pro-organizational influence behavior to be at work today.

Image management behavior. Image management behavior is a subtle way to influence superiors with the objective of achieving personal gain, in addition to organizational benefits. Individuals engage in such favor-seeking behavior to gain acceptance from the superiors controlling the rewards and enhancing one's self-image to others (Liden and Mitchell, 1988). An example of image management influence behavior is to learn the likes and dislikes of important people in the organization to avoid offending them. We propose that, holding other factors constant, the longer the communist footprint, the less subordinates perceive image management behavior as acceptable.

First, communism indoctrinated individuals to keep a low profile and avoid rocking the boat (Napier and Thomas, 2004; Puffer, 1994). Often, individuals who aspired to advance in their careers resorted to seeking promotions through favors from their superiors. In Russia, such personal -seeking is known as blat (Fitzpatrick, 1999; McCarthy \& Puffer, 2008). Despite the prevalence of blat, the average worker in the former Soviet Union looked at it with "disgust" (Harris, 1997: 206), a "pathology, something fundamentally deviant and alien to Russian society" (Fitzpatrick, 1999: 64). The reason is that it evoked negative connotations with swindlers, cheaters, thieves, and tattlers (Fitzpatrick, 1999). Thus, blat was used secretly, as fellow co-workers disapproved toadying to superiors. They perceived such ingratiating behavior as delegitimizing the promotion-seeker, because he/she did not obtain the promotion on merit (Fitzpatrick, 1999; Pearce, 1991). Such individually centered image management tactics were perceived to raise the bar for the expected performance and, ultimately, survival in the organization for all subordinates. Traditional fairness heuristic theory (van den Bos et al., 1997a, b) helps explain why personal ambition to over-achieve was judged as unfair to the group and was resented by the group: it was viewed as trying to take away employees' fair share of limited resources (Puffer, 1994). Thus, a longer communist footprint marks subordinates' perception that image management behavior is less acceptable to get ahead at work today. 
Conversely, a shorter communist footprint indicates that the subordinates have experienced market liberalization earlier in their lives. Market liberalization captivates superiors' attention on how to stay viable in the face of increasing competition (Chari and Banalieva, 2015). To filter through such information overload (Nadkarni and Barr, 2008), subordinates with shorter communist footprints would perceive competing for their superiors' appreciation as normal, especially by taking initiatives that would make them look better. Individuals who experienced market liberalization earlier in their socialization could more easily shift their mindset away from thinking there is an equal share of the pot for everyone and toward realizing that they would only be rewarded commensurate with their performance. This is in line with international management research suggesting that individuals with shorter communist footprints embraced much more easily the Western capitalist work ethic that wealth accumulated through hard work is virtuous, individualism accompanied by personal accountability for one's actions is not wrong, and some healthy competition is desirable (Boobbyer, 2005; Linz and Chu, 2013; Sexty, 1998). These individuals understand that their organizations expect high personal accountability and moral standing to be promoted further, and that ingratiation for the sake of simply promoting one's self is not acceptable. This, in turn, helps curtail possible antiorganizational behaviors. Linz and Chu (2013) found that these individuals were 10\% more likely than their colleagues with longer communist socializations to agree with the statement that "hard work makes one a better person" and "better to have a job with a lot of responsibility" (p. 199-200). This is also in line with fairness heuristic theory noting that employees reciprocate fair treatment by their organizations with likewise pro-organizational behaviors (Chiaburu and Lim, 2007). Thus, a shorter communist footprint indicates that subordinates would perceive image management behavior as more acceptable at work today.

Second, communism suggests that individuals with longer communist footprint grew accustomed to engaging in ceremonial management: the performance of activities in an apparent compliance with superiors' orders (Tsoukas, 1994). Individuals who were socialized longer into such make-believe practices were accustomed to keeping the appearance of going through the right motions (Tsoukas, 1994). For instance, such individuals perceived as normal that fellow co-workers padded production numbers to give the appearance of meeting the unrealistic government-imposed 
economic targets (McCarthy and Puffer, 2008). Ceremonial management covered for the lack of interest to display initiative. Image management behavior, on the other hand, demands that subordinates take initiative and volunteer to over-perform in projects for the organization that would make the subordinates look good and that would benefit the organization. A longer communist footprint indicates that the subordinates are likely to perceive such initiative-taking to be overlyzealous and unnecessary, given its stark contrast to the low profile-mindset that was the norm during communism.

Conversely, a shorter communist footprint indicates that the subordinates have likely been socialized into a greater acceptance of individuals who stand out from the crowd. Market mechanisms promote individualism, private property, and personal freedom rights (Chari and Banalieva, 2015). The transition from central planning to a market economy fundamentally ushers in mutual expectations for individual behavior that promote greater economic activity. A shorter communist footprint indicates that the subordinates would perceive self-promoting image management behavior as playing by the rules. Such individuals would likely adopt less negative fairness judgments about their brief communist socializations, as they would perceive image management influence behavior as normal (Pucetaite and Lamsa, 2008). Thus, we propose that holding other factors constant:

H1b: In post-communist transition economies, the longer the communist footprint, the less acceptable subordinates perceive image management influence behavior to be at work today.

\section{Subordinate Communist Footprint and Organizationally Destructive Influence Behavior}

We study two core types of organizationally destructive influence behaviors: self-serving and maliciously intended (Ralston et al., 2013).

Self-serving behavior. Self-serving behavior benefits the individual (Ralston et al., 2009). Unlike image management behavior, which benefits both the individual and the organization, selfserving behavior does not necessarily have a positive effect on the firm. Self-serving behavior captures self-interest that is placed before the interests of others. An example is taking credit for a good job that was done by another colleague. We propose that, holding other factors constant, the longer the communist footprint, the more the subordinates perceive self-serving behavior as acceptable at work today. 
First, communism imposed unrealistic government expectations on companies and employees (McCarthy and Puffer, 2008; Puffer, 1994). The state often fell short of providing sufficient resources but, nonetheless, demanded much in return (Pearce, 1991). People who were socialized longer under communism accumulated stronger negative judgments against such unfair procedures from the powerful authority of the state. Traditional fairness heuristic theory warns that "unfairly enacted procedures decrease followers' trust in the authority particularly when authorities have greater power over the followers" (van Dijke et al., 2010: 488). Consequently, a longer communist footprint indicates that subordinates grew up in an environment where engaging in doublethink was customary for survival (Pearce, 1991; van Dijke et al., 2010; Uslaner and Badescu, 2004). Doublethink meant that it was acceptable to lie about performance indicators to receive positive feedback and evaluations from superiors. Thus, a longer communist footprint increases the acceptance of using somewhat deceptive, self-serving behavior.

Conversely, a shorter communist footprint indicates that subordinates may find such selfserving doublethink behavior less acceptable due to their earlier experiences with capitalist economic and governance improvements, accompanied by the implementation of efficient monitoring and performance mechanisms on the job (Chari and Banalieva, 2015). The earlier in life an individual experienced this new market reality, the quicker that individual learns to adopt it and demand from fellow colleagues more responsible work behavior. For instance, these individuals observed earlier in their socialization that codes of ethics began being developed to promote personal accountability in the new economy, and those who were frequently absent from work, cheated on performance evaluations, or missed performance targets were strictly sanctioned (Linz and Chu, 2013; Sexty, 1998). Additionally, Jaffe and Tsimerman (2005) found that $91 \%$ of such individuals support rules and codes, meaning they believe it is important to comply with the law and expected professional standards, and $83 \%$ support the view that everyone should stick to the established rules and procedures in their organizations. According to traditional fairness heuristic theory, individuals with shorter communist footprints are much more likely to perceive such sanctions as fair, which would further encourage them to engage in constructive influence behavior (van Dijke et al., 2010). This is also supported by cross-cultural management research finding that individuals who were socialized 
for very little under communism were more likely to embrace the strong work ethics typical for capitalist market economies (Linz and Chu, 2013). Accordingly, a shorter communist footprint raises the subordinates' acceptance of the new market-oriented mindset of work diligence and honesty at work, thus decreasing the perceived acceptability of self-serving behavior.

Second, communism also created an environment where it was acceptable for a superior to turn a blind eye to subordinates' minor transgressions that could hurt the organization (Pearce, 1991). Individuals with a longer communist footprint grew accustomed to supervisors covering for their employees in frequent cases of absenteeism or stealing organizational resources for personal use (Pearce, 1991). Such practices occurred often during communism because they legitimized the superior in the eyes of the subordinates and ensured that the superior could, in turn, demand some actual effort from their subordinates in meeting the government plans (McCarthy and Puffer, 2008). Thus, a longer communist footprint indicates that the subordinates have likely grown accustomed to bargaining over assignments and payments with superiors and, hence, are more accepting of using self-serving behavior.

Conversely, a shorter communist footprint indicates that the subordinates may find such selfserving informal cover-up behavior less acceptable. The new market rules of the game require a much more formalized work environment, with explicit contracts, deadlines, and performance indicators (Chari and Banalieva, 2015). Earlier socialization with this new market reality accustoms individuals to seeing superiors being sanctioned for dishonest work practices (Linz and Chu, 2013). Thus, the shorter the communist footprint, the greater the subordinate's adaptation to the new market reality of more transparent subordinate-superior work relationships. Thus, we propose that holding other factors constant:

H2a: In post-communist transition economies, the longer the communist footprint, the more acceptable subordinates perceive self-serving influence behavior to be at work today.

Maliciously intended behavior. Maliciously intended behavior benefits the individual and deliberately tarnishes the organization (Ralston et al., 2013). It may be described as a burn/pillage/plunder approach to gain influence in an organization due to counterproductive behavior (Ralston and Pearson, 2010). An example is to threaten to give valuable company information to an 
outsider if one's demands are not met. We propose that, holding other factors constant, the longer the communist footprint, the more subordinates perceive maliciously intended behavior as acceptable at work today.

First, communism imposed top-down, authoritarian rule with little or no room for dissent (Napier and Thomas, 2004). The prolonged subjugation to this authoritarian rule sustained a belligerent work atmosphere that resulted in divergent subordinate-superior goals. While superiors were scurrying to meet state plans, subordinates were scouting for opportunities to bypass authority to preserve their personal autonomy (Pucetaite and Lamsa, 2008). In such authoritarian contexts, individuals approach their tasks reactively with the philosophical perspective: "When rules were immoral, rule breaking became a moral act" (Pearce, 1991: 82). Thus, a longer exposure to communism may indicate an enhanced perception that aggression to succeed at work is an acceptable behavior. Individuals with longer communist footprints grew accustomed to looking for ways to game the system to ensure their personal survival, without regard to this behavior hurting the company. Reoccurring behavioral patterns were formed habituating people to feel entitled to seek their own share through any means possible to guarantee their personal survival, as the state and organization did not have their best interest in mind (Pop-Eleches and Tucker, 2014). A prolonged exposure to the unfair labor practices of communism sustained a chronic attention on self-interest, rather than others' interest, as a powerful coping mechanism perceived as fair (Bobocel, 2013).

Conversely, a shorter communist footprint indicates that subordinates would find maliciously intended behavior to be unfair to the organization. Such individuals have been socialized much earlier in their lives into the participative decision-making style that market liberalization ushers into organizations (McCarthy and Puffer, 2008). They are more likely to comply with decisions that they are able to influence and to understand the rationale (Danis et al., 2011). Thus, a shorter communist footprint indicates the subordinates have socialized much earlier with others who trust their firm and perceive their individual goals aligned with those of the firm.

Second, communism also imposed senseless regulations on individuals that significantly increased individuals' frustration with the bureaucratic system (Puffer and McCarthy, 1995). These mindless regulations encouraged the views that abidance by these laws was not equally demanded 
from all citizens. The ruling bureaucratic elite could bypass them with bribery while the common person could not (Pearce, 1991). As such, the laws under communism were perceived as unjust and justifiable to be circumvented (Sexty, 1998). In line with traditional fairness heuristic theory, "when uncertainty is coupled with clearly unfair treatment, the person will engage in self-protective or even competitive actions, in order to relieve uncertainty by seizing control of his or her own fate and identity" (Lind and van den Bos, 2002: 196). Thus, self-interest prevails for individuals with longer communist footprints because concern for the good of one's self far outweighed concern for the good of the organization (Lind and van den Bos, 2002). Such prolonged communist experiences strengthened resentment of authority.

Conversely, a shorter communist footprint relates to subordinates who are "the first generation that will have no doubts about the need for a market economy" (Puffer, 1993: 477). Having socialized earlier under the new market reality, such individuals learn very early that adding value to an organization is rewarded while deliberately tarnishing the organization is not. Even though individuals with a shorter communist footprint may have socialized with parents and teachers with a longer communist footprint, research shows that they give much more priority to concerns regarding "expected punishments or rewards" and "law and order" than to "the acceptance of those close to me" (Jaffe and Tsimerman, 2005: 94). Accordingly, the reforming legal system and improving governance and transparency under market capitalism have a stronger effect on these individuals. Overall, this research concludes that people who are socialized earlier in their lives with a higher ethical standard, value it more later in life (Linz and Chu, 2013). Such an early contact with the higher ethical standard ensuing from market liberalization helps people realize that the reputation risks from initiating questionable business practices may not be worth it. Additionally, individuals with shorter communist footprints were not old enough to experience first-hand the persistent state spying on individuals' personal lives at work to the extent that their longer communist footprint counterparts did. The individuals with shorter communist footprints would hear stories through their social interactions under communism that the state required companies to collect detailed files on their workers' personal lives and release them at the state's whim (Ryan, 2006). In line with traditional fairness heuristic theory, these individuals are likely to form negative judgments against this unfair communist practice 
and embrace the new market-based reality of formalized codes of ethics and protection of personal liberties from state intrusions (van den Bos et al., 1997a, b). As such, they are more likely to disapprove of malicious influence behaviors at work today as they have experienced first-hand the benefits of employee rights and opportunities for growth based on an individual's merit that abound under market conditions. Thus, we propose that holding other factors constant:

\section{H2b: In post-communist transition economies, the longer the communist footprint, the more acceptable subordinates perceive maliciously intended influence behavior to be at work today.}

\section{The Moderating Role of the Subordinate's Position Level in the Company}

The aforementioned Hypotheses 1a through $2 \mathrm{~b}$ assumed that the communist footprint has the same direct effect on influence behaviors at work today for all communist-socialized individuals, regardless of their situational context. We next relax this assumption by drawing from recent advances in fairness heuristic theory (Fortin et al., 2014; Jones and Starlicki, 2013) and imprinting theory (Simsek et al., 2015) calling for a more nuanced understanding of the conditions under which imprints can be weaker for some individuals than for others, and if so, under what contexts.

Fairness heuristic theory notes that individuals have a fundamental need to understand how they fit in their situational contexts and what the appropriate behaviors for these contexts are (Jones and Starlicki, 2013). In fact, individuals are "disciplined by the social context in which they find themselves" (Dutton et al., 1997: 409). An important situational context for any working individual is their position in the company: lower-level positions (non-supervisory staff and first-level managers) or higher-level positions (middle- and upper-level managers) (Ahearne et al., 2014). Since different positions carry different expectations from professionals, they are likely to further modify the aforedeveloped communist footprint-influence behaviors baseline relationships (Chen, 2014; Trevino et al., 2008). We analyze these moderation effects next. For ease of exposition and page limitations, we focus our moderation arguments on the individuals with a longer communist footprint. We expect $a$ priori that the moderation arguments would be weaker for the individuals with shorter communist footprints because they experienced communism only briefly, so their negative fairness judgments against the communist authority would likely be weaker than those of their longer communist footprint counterparts. 
Constructive influence behavior relationships. We propose that occupying a higher position in the organizational hierarchy reduces the negative impact of the communist footprint on organizationally constructive behaviors as it shifts these individuals' attention to advancing their company's goals and strategies rather than sabotaging them.

At higher levels of the organization, the individuals with longer communist footprints will perceive pro-organizational behaviors to be more appropriate than their counterparts at lower position levels as the former tend to identify more with their organizations (Chen, 2014; Siu and Lam, 2009; Yang, Zhang, and Tsui, 2010). They know they have a hand in shaping their organization's strategy while their lower-level counterparts with longer communist footprints simply follow it, just as they got accustomed to follow orders during communism (Trevino et al., 2008). Individuals with longer communist footprints who are also higher in the organizational hierarchy have first-hand memories of their colleagues' struggles to meet high government expectations with scant resources during communism. We expect that occupying a higher-level position in the organization shifts the attention of these longer-communist footprint individuals on the well-being of their subordinates and organization, and attenuates the mindset that was instilled in them during communism that a leader has to be authoritarian and self-centered to avoid looking weak in the eyes of subordinates. Because higher-level managers with longer communist footprints strongly identify with their organizations (Puffer et al., 1997), they value the importance of maintaining the organizations' respectable reputation for various stakeholders more than their lower-level counterparts (Chen, 2014). As such, these managers tend to work excessively long hours, have a profound respect for their subordinates, and perceive their jobs as their life's central focus (Puffer et al., 1997; Veiga et al., 1995).

Higher-level managers with a longer communist footprint also occupy positions with great authority and responsibility. They give direction to their subordinates and receive such from their senior management (Ahearne et al., 2014). Despite their longer communist footprint, they are less likely to feel vulnerable to exploitation by their senior management superiors as their position requires them to contribute ideas to the overall strategy making process (Lind, 2001). As such, they are less likely to be accepting of unproductive behaviors such as gamesmanship, breaking the rules to get the job done, bad-mouthing, or putting off important tasks as they would have to report progress to their 
senior management supervisors (Kuratko and Goldsby, 2004). Thus, higher-level managers with a longer communist footprint would likely perceive that giving their best for the organization's advancement is the appropriate behavior for their role while insisting on grabbing from the organization what might be their rightful share, a mindset prevalent during communism, is an inappropriate behavior for their high-level positions at work today. They would likely perceive proorganizational behaviors as less risky as they know they are in a position to help shape the organization's success, or be fired if they don't (Trevino et al., 2008). Since their organizational commitment is strongly aligned with that of their superiors, they are less likely to approve of selfcentered actions that would hurt their organization. They would also be less likely to adhere to the communist-inherited mindset of constantly being on the lookout as to how they compare to others.

Conversely, at lower levels of the organization, individuals with longer communist footprints are more likely to continue being cynical toward their organizations due to their continual lack of political power to influence their organizations' strategy (Siu and Lam, 2009). A longer communist exposure has taught these individuals that they can survive only if they look out for themselves first. This self-centered and organizationally-indifferent mindset typical for individuals with longer communist footprints is likely to be reinforced for those individuals who are at lower positions in their organizations today. The reason is that lower-level employees have limited access to resources as compared to their higher-level counterparts. The lack of political power within their organizations is even more problematic for the morale of individuals with longer communist footprints as it renders them more likely to feel stressed about making do with scarce resources, just as they were during their prolonged communist pasts. Accordingly, these individuals would feel just as exploited now as they felt under their prolonged experiences with the communist authority. The lower position in their organizations is also more likely to reinforce their communist-inherited belief that formal ethics codes in their organizations are nothing more than "window dressing" to protect upper-level management if a scandal arises that threatens the organizational reputation (Trevino et al., 2008: 238). Such makebelieve management practices were, indeed, very common during communism (Tsoukas, 1994). Thus, we propose: 
H3a: In post-communist transition economies, the longer the communist footprint, the more acceptable pro-organizational influence behavior becomes for individuals at higher-level positions than for individuals at lower-level positions.

Similarly, we expect that for image management behaviors, a higher position-level in the company reinforces the sense of paternalistic responsibility that individuals with longer communist footprints have for their subordinates that was instilled during the communist propaganda for how each individual should contribute to the community's well-being (Puffer et al., 1997). The higher position level in the company shifts these individuals' attention on the power they hold now as important brokers between senior management and lower-level professionals (Floyd and Wooldridge, 1994). As such, these individuals realize that they are now tasked with identifying the obstacles that threaten the success of their organizations and propose ways to overcome them (Kuratko and Goldsby, 2004). As they occupy three different role sets—as superiors to the lower-level professionals, peers, and subordinates to executive management (Tsui, 1984)—-higher-level managers with longer communist footprint would be more likely to perceive leveraging their different networks and engaging in image management influence behaviors as acceptable to advance the success of different projects that benefit the organization. A key reason is that these individuals were socialized into the communist system of favor-giving and favor-receiving to meet government expectations (Puffer, 1994). Thus, issue selling, to gain senior management's attention on problems, would be perceived as acceptable for their higher-level position.

Additionally, we expect that a higher position-level in the company reinforces the sense of personal responsibility that individuals with longer communist footprints have carried forward from communism to project a positive self-image to the subordinates who are under their care and who they must convince to follow the strategy that senior management chose. Individuals with longer communist footprints were accustomed to working hard to ensure their subordinates meet the government expectations despite the limited resource and time quotas given to them (Puffer, 1993; Tsoukas, 1994). Occupying a higher-level position in the company today means that the pressure to perform well is even higher for these longer communist footprint individuals, as they risk dismissal in the event of failure to perform their duties. Accordingly, not engaging in image management 
influence behaviors will likely be perceived by these higher-level managers with longer communist footprints as naïve and risky of losing face in front of both their CEO and subordinates (Dutton and Ashford, 1993). Such a failure would jeopardize their position in the company. Hence, these managers would likely perceive image management influence behaviors as acceptable to reach the desired organizational goals (Dutton et al., 1997). Thus, we propose:

\section{$H 3 b:$ In post-communist transition economies, the longer the communist footprint, the more acceptable image management influence behavior becomes for individuals at higher-level positions than for individuals at lower-level positions.}

Destructive influence behavior relationships. Conversely, we propose that occupying a higher position in the organizational hierarchy reduces the positive impact of the communist footprint on organizationally destructive behaviors as it shifts these individuals' attention to paternalistic care for their subordinates rather than self-centered indifference toward or sabotage of their organizations.

We expect that a higher position-level in the company reinforces the heightened sense of "moral commitment" to care for and protect their subordinates that individuals who were extensively socialized under communism have developed (Puffer, McCarthy, and Naumov, 1997: 264). This is a remnant of their communist indoctrination of community focus where managers were expected to be responsible not only for meeting government quotas but also for the food, health, housing, day care, and other aspects of their employees' lives. Thus, higher-level positions of authority compel the individuals with longer communist footprints to prioritize their sense of paternalistic care over personal self-serving gain (Puffer et al., 1997; Veiga et al., 1995).

Once in a position of authority over other people's lives, higher-level managers who were exposed to communism for longer do not have the luxury to focus on self-serving cues as those do not advance the company but only themselves. Managers' personal identity grows more inter-connected with their organizational position the higher in the hierarchy they reach (Chen, 2014; Trevino et al., 2008). Hence, the social context of upper-level positions in the company teaches these managers that appropriate behavior at this level is striving to promote the organization's well-being rather than only their own because they are held personally responsible for their actions through regular progress reports to the CEO (Yang et al., 2010). As individuals with longer communist footprints have a long experience with creative problem solving to meet unrealistic government quotas with scarce resources 
under the communist regime (Puffer, 1994), they become even more sensitive to group-related cues such as joint success of the team as their position level in the company increases. The reason is that such individuals with longer communist footprints who are also high in the organizational hierarchy realize that the CEO is more interested in the success of the entire team for the organization to succeed. This is why these individuals are more likely to protect the interests of the staff under their care and promote the well-being of the entire organization (Bobocel, 2013). Thus, we propose:

H4a: In post-communist transition economies, the longer the communist footprint, the less acceptable self-serving influence behavior becomes for individuals at higher-level positions than for individuals at lower-level positions.

Similarly, we expect that for maliciously intended behaviors, a higher position-level in the company dismisses possible preoccupation of the individuals with longer communist footprints with being victims of the communist regime. Individuals with longer communist footprints who are currently at higher-level positions in their organizations are less likely to still ruminate on how unfair their communist pasts may have been, and instead are more likely to refocus their current creative energy to helping their organizations succeed. Indeed, fairness heuristic theory suggests that when individuals feel harmed, the ones in lower positions with no or limited authority are much more likely to seek revenge for their perceived injustices than the ones higher in the organizational hierarchy (Aquino et al., 2006; Tripp et al., 2007). This is in line with the theory's premise that how people cope with unjust events can be modified depending on the interplay between contextual and dispositional factors (Aquino et al., 2006; Bobocel, 2013; Dutton et al., 1997). Higher-level managers have a surplus of self-affirming symbolic accolades such as prestigious titles, connections with senior executives, and important assignments that lower-level professionals lack (Tripp et al., 2007). Thus, a higher-level position reinforces the communist-inherited focus on status and power within organizations for individuals with a longer communist footprint that compensates for their previouslyaccumulated negative judgments against superiors. As such, they would be less likely to engage in maliciously intended influence behaviors than their lower-level counterparts. Conversely, lower-level professionals, especially those with a longer experience with the communist unfair practices, would still dwell on how ill-equipped with resources they are even today, and may be more likely to be accepting of maliciously intended influence behaviors to advance themselves at work (Chen, 2014). 
Furthermore, higher-level managers with a longer communist footprint would be more likely to find maliciously intended behaviors unacceptable because they have more information on how their organizations discipline unethical behaviors (Chen, 2014). Since "where you sit may determine what you see" (Pratt and Rafaeli, 1997: 887), it is higher-level managers who may be privy to information about such disciplinary action as it usually involves sensitive and confidential information (Dutton and Ashford, 1993; Trevino et al., 2008). Access to such private information helps higher-level managers with longer communist footprints trust their CEO more than their lower-level counterparts that impartial punishments would follow unethical practices. At the same time, lower-level professionals with a longer communist footprint are more likely to be attuned to recognizing unethical practices in their daily work but not take action against them (Trevino et al., 2008). A key reason is that they have "awareness, combined with less information about the punishment of unethical conduct," which reinforces their defeatism and cynicism toward their superiors (Trevino et al., 2008: 238). Therefore, we hypothesize:

H4b: In post-communist transition economies, the longer the communist footprint, the less acceptable maliciously intended influence behavior becomes for individuals at higher-level positions than for individuals at lower-level positions.

\section{METHODOLOGY}

\section{Data and Sample}

We tested our framework with data from a mail survey of subordinates working in organizations in Bulgaria, Croatia, Czech Republic, Hungary, Lithuania, Russia, and Slovenia. We identified the transition economies following de Melo et al. (1997: 53). The data were collected as part of a larger study on global ethics and values, ranging from 2001 to 2011 . Thus, our ability to collect survey-based multi-year and multi-country data alleviates concerns in the literature that most international management survey research has focused on single country samples (Bruton and Lau, 2008), and contributes empirically to the literature on Eastern Europe (Meyer, Estrin, Bhaumik, \& Peng, 2009).

The questionnaire was originally prepared in English and then translated into each of the native languages of the countries. We used standard translation/back-translation procedures (Maxwell, 
1996). Most of the respondents were from different companies in their countries (no more than five/company). The response rate was $16 \%$ across the seven transition economies, and was comparable with that of other survey studies on non-traditional contexts, such as those of transition economies (Harzing, 1997).

Our sample consisted of 1,393 communist-socialized professionals (Bulgaria: 83, Croatia: 233, Czech Republic: 280, Hungary: 120, Lithuania: 279, Russia: 110, and Slovenia: 288). All respondents were born in and had lived for the first 15 years of their lives in the sampled country. We excluded individuals born prior to the starting year of communism, as well as during or after the starting year of market liberalization to ensure that all had a communist footprint. The start of communism was 1948 for Bulgaria, Czech Republic, and Hungary; 1945 for Croatia, Lithuania, and Slovenia; and 1918 for Russia (Hernández-Catá, 1998). The start of market liberalization was 1990 for Bulgaria, Croatia, the Czech Republic, and Slovenia; 1989 for Hungary; 1991 for Lithuania; and 1992 for Russia (Falcetti et al., 2002).

\section{Measures}

Dependent variables. Consistent with prior research, we used the subordinate influence ethics (SIE) questionnaire to capture our four dependent variables (Karam et al., 2013; Ralston et al., 2013). The SIE instrument was designed to assess participants' perceptions of the acceptability of different influence behaviors within their organizations, and was cross-culturally validated (Ralston and Pearson, 2010).

To reduce the possible influence of social desirability bias, we used two approaches. First, we used the recommended "other-report" format instead of the "self-report" format (e.g., Anastasi, 1982; Ralston and Pearson, 2010). Thus, each SIE scenario item asked the responders to indicate "how acceptable [ethical] you think that your co-workers would consider each strategy as a means of influencing superiors." Self-report measures open the possibility for the responders to distort their true responses to hide personal insecurities or protect self-image (Anastasi, 1982). Conversely, otherreport measures as the ones used in our paper focus the responders' attention on the typical behavior of their co-workers, thus reducing the responder's need to be defensive and/or secretive in his/her responses. 
Second, we used scenario rather than direct expression questions, as the former have been shown to substantially reduce social desirability issues in cross-cultural research (Miller et al., 1999; Trianidis, Chen, and Darius, 1998). Accordingly, the SIE comprises 24 short scenarios, of which 22 constitute the four SIE dimensions (Appendix 1). Responses to these 22 scenarios were scored on an 8-point Likert-type scale $(1=$ extremely unacceptable behavior to $8=$ extremely acceptable behavior $)$ (Karam et al., 2013; Ralston and Pearson, 2010). As such, the SIE instrument captures the full gamut of organizationally constructive and destructive influence behaviors in a hierarchy that exists across countries: Pro-Organizational > Image Management > Self-Serving > Maliciously Intended (Ralston et al., 2009, 2013). Participants' scores for the four influence dimension scales were calculated by averaging the relevant items. The internal reliability (Cronbach alpha) for the four SIE dimensions for our sample was 0.69 for pro-organizational behavior ( 6 items), 0.67 for image management behavior ( 5 items), 0.64 for self-serving behavior ( 6 items) and 0.64 for maliciously intended behavior ( 5 items). Established research has used an alpha of 0.7 to show internal reliability (for an overview, see Henson, 2001). However, Nunnally (1967) noted that for research in its early stages, "reliabilities of 0.60 or 0.50 will suffice" (p. 226). Our research is indeed in its early stages as, besides Danis et al. (2011) who analyzed the communist imprint, we are not aware of other research that has analyzed the effect of the communist footprint on subordinates' work behaviors. Thus, since all of our alphas are above 0.6 , they pass Nunnally's test for internal reliability. These scores are further consistent with cross-cultural research studying influence behavior in organizations (Fu and Yukl, 2000; Ralston et al., 2014). Too high alphas, on the other hand, have also been deemed problematic as they indicate scale item redundancy (Boyle, 1991).

Independent variable. We captured the Subordinate Communist Footprint with the number of years lived under communism since the individual's birth year. The variable ranged from 2 to 46 (average of 23.49 years), providing sufficient heterogeneity to test our framework.

Moderator variable. We captured the key moderator in our study-Position Level—with 1 for employee, 2 for first level manager, 3 for middle level manager, and 4 for upper level manager (Ralston et al., 2013). Thus, higher values of the variable indicate the individual occupies a more senior position. 
Interaction. To test the moderation hypotheses, we included the Subordinate Communist Footprint * Position Level interaction.

Control variables. We controlled for individual, company, and country-level factors.

At the individual level, we controlled for the subordinate's Gender (1 for female, 0 for male), Education ( 1 for 4 or fewer years completed, 2 for 5-8 years, 3 for $9-12$ years, 4 for undergraduate university, 5 for Master's degree, 6 for Doctorate degree), and Reform Footprint (number of years lived under market liberalization after the fall of communism, whereby the sum of Reform Footprint and Communist Footprint exactly equal the individual's age, so controlling additionally for age is redundant).

At the company level, we controlled for Company Size ( 1 for $<100$ employees, 2 for 100 1,000 employees, 3 for > 1,000 employees) and Industry ( 1 for manufacturing/natural resources, 0 for other). At the country level, we controlled for Country Effects with six 0/1 country dummies and used the seventh - Lithuania -as the base category. We also accounted for home country economic institutions (current and prior) and political institutions (current and prior) (Egri et al., 2000; Karam et al., 2013; Ralston et al., 2009). We captured the current economic institutions with the average of the Heritage Index of Economic Freedom (Holmes et al., 2008). Since 2004, the Heritage Index has started tracking a labor component too. To ensure comparability across the survey period in our study, we excluded the labor component and computed the index as the average of the remaining nine components. The original index ranges from 0 to 100 , but we rescaled it from 0 to 1 by dividing the index variable for each country by 100 for greater scale comparability. We captured the prior economic institutions with the value of repressed inflation just before the fall of communism (i.e., the difference between growth in real wages and real GDP growth over 1987-1990) (de Melo et al., 1997: 44-46). We captured the Current Political Institutions with the degree of regulation of political participation from the Polity IV database (Marshall et al., 2011), ranging from 1, the unregulated political system of no enduring political groups or control on political activity due to recurring coercion, to 5, regulated political system, where stable political groups compete for political influence with little use of coercion. We captured the prior political institutions with the average level of 
democracy in the country during communism, also obtained from the Polity IV database (Marshall et al., 2011). The variable was averaged over the communist period in each country, including the democracy values in the starting year of communism and excluding the democracy values in the starting year of reforms in each country. In computing the average value of the prior political institutions, we counted Croatia and Slovenia as parts of former Yugoslavia, Lithuania as part of former USSR, Russia as part of former USSR after 1922, and the Czech Republic as part of former Czechoslovakia. Lastly, we controlled for survey year (Pop-Eleches and Tucker, 2014).

\section{Statistical Analysis}

We first tested our data for common method variance (Podsakoff and Organ, 1986). All variables were entered into an exploratory factor analysis using unrotated principal components and principal component analysis with varimax rotation. The results indicated 8 factors with eigenvalues greater than 1.0, which together accounted for $76.73 \%$ of the total variance. The largest factor did not account for a majority of the variance either (21.46\%). Moreover, the confirmatory factor analysis showed that the single-factor model did not fit the data well. In sum, common method variance does not bias our results.

We also considered the cross-cultural equivalence of our data. Using a multi-method approach in cross-cultural research helps yield more reliable results and reduce possible biases that may obtain in such research (Samiee and Jeong, 2004). Our methodology is multi-method as it includes survey design, back-translation, multivariate and hierarchical analyses, and a series of robustness tests to account for alternative explanations of our results. We abide by established best practices that the survey design team should include researchers from the sampled countries to avoid potential biases: all our data were collected, translated, and back-translated, by colleagues who are natives of the seven countries (Samiee and Jeong, 2004; Schaffer and Riordan, 2003). The questionnaire was designed by first obtaining feedback from these colleagues how each question may be understood in the context of their countries. This is also recommended best practice of a "derived etic" approach where the researchers first obtain emic knowledge about the culture either through observation or actual participation (Schaffer and Riordan, 2003). As the goal of our paper is not to test new theory but extend an existing theory (imprinting theory) to new contexts (communist footprint), 
shared frames of reference can be assumed across cultures (Berry, 1979; Morris et al., 1999; Schaffer and Riordan, 2003). When researchers are interested in individual-level rather than country-level differences in the dependent variables, as we are, pooling of the data with a technique to control for country-level unobserved heterogeneity has been shown to be appropriate (Linz and Chu, 2013). Overall, we balanced the financial and time challenges in conducting cross-cultural research with adherence to established cross-cultural survey guidelines.

We next tested our conceptual framework with ordinary least squares regression and robust standard errors, as in similar survey-based studies with Likert-scaled dependent variables (Christmann, 2000). We centered the Subordinate Communist Footprint and Position Level main effects and formed the interaction from their centered values. It should be noted that although country dummies were included in all regression analyses as level-2 controls, SPSS ultimately set them to zero due to parameter redundancy. We present robustness tests that provide an alternative method to account for unobserved country heterogeneity (Appendix 2, Table A). Furthermore, we later used an alternative methodology that could capture possible nesting effects of individuals nested in countries-hierarchical linear modeling (HLM) (Bruton and Lau, 2008; Raudenbush and Bryk, 2002) — and obtained qualitatively similar results (Appendix 2).

\section{Results}

Table 1 presents the descriptive statistics. Table 2 presents the results from the full model specifications containing the direct effect, moderator, interaction, and control variables (Brambor, Clark, and Golder, 2006). We proposed that, keeping the centered position level at zero which occurs empirically when position level is at its average, a longer communist footprint reduces the acceptability of pro-organizational (H1a) and image management (H1b) influence behaviors. We found support for both: beta $=-0.011, \mathrm{p}<0.001$ for H1a and beta $=-0.020, \mathrm{p}<0.001$ for $\mathrm{H} 1 \mathrm{~b}$. We also proposed that, keeping the centered position level at zero which occurs empirically when position level is at its average, a longer communist footprint increases the acceptability of self-serving (H2a) and maliciously intended ( $\mathrm{H} 2 \mathrm{~b})$ influence behaviors. As noted in Table 1 and 2, we did not find support for either of these direct effects at conventional statistical levels, on which we elaborate in our Discussion section. 


\section{[TABLES 1-2 HERE]}

We further proposed that a higher position level reduces the baseline negative effect of a longer communist footprint on the acceptability of pro-organizational (H3a) and image management (H3b) influence behaviors. We did not find support for either of these interaction effects at conventional statistical levels, on which we elaborate in our Discussion section. We further proposed that a higher position level reduces the baseline positive effect of a longer communist footprint on the acceptability of self-serving (H4a) and maliciously intended (H4b) influence behaviors. We found support for both: beta $=-0.015, \mathrm{p}<0.001$ for $\mathrm{H} 4 \mathrm{a}$ and beta $=-0.006, \mathrm{p}<0.05$ for $\mathrm{H} 4 \mathrm{~b}$.

Figures $2 \mathrm{a}$ (with self-serving) and $2 \mathrm{~b}$ (with maliciously-intended) plot these significant interaction effects, providing visual support for our hypotheses (Aiken \& West, 1991). Figure 2a shows length of communist footprint (years) on the $\mathrm{x}$-axis and the level of perceived acceptability of self-serving behaviors on the y-axis. At lower levels of communist footprint (up to about 29 years of experience with communism), individuals at higher level positions in their organization perceived self-serving behaviors as more acceptable than their lower-level position counterparts. However, this reverses as communist footprint grows beyond 29 years such that individuals at higher level positions in their organization perceived self-serving behaviors as less acceptable than their lower-level position counterparts, in line with our theoretical predictions.

To further probe the significance of the interaction term in Figure 2a, we conducted the change in $\mathrm{R}^{2}$ and simple slope tests. The change in $\mathrm{R}^{2}$ test noted that a significant portion of the variance in the perceptions of the acceptability of self-serving behaviors was increased with the addition of the interaction term $\left(\Delta \mathrm{R}^{2}=0.011, \mathrm{p}<.000\right)$. Thus, the test shows that position level moderates the effect of communist footprint on self-serving behaviors, as evidenced by a statistically significant increase in total variation explained of $1.1 \%, F(1,1338)=16.94, \mathrm{p}<.0005$. This test suggests that the slopes of the two regression lines for high and low position levels are statistically different. The simple slope test further indicated that for high position individuals, the relationship between communist footprint and self-serving behavior is statistically significant $(p<.011)$ and negative $(-0.029 \pm 0.011)$. For low position individuals, the simple slope test indicated that the 
relationship between communist footprint and self-serving behavior is negative $(-0.005 \pm 0.010)$ but not significant $(p=0.65)$. As prior research notes, "the significance of the interaction term remains the main criterion for rejecting the null hypothesis" (D'Angelo, Majocchi, \& Buck, 2016: 9, also see Dawson, 2014). Since the regression coefficient of the interaction term in Table 2 was significant, we conclude that the effect of communist footprint on self-serving behaviors depends on position level.

Similarly, Figure $2 \mathrm{~b}$ shows that at lower levels of communist footprint (up to 38.75 years of experience with communism), individuals at higher level positions in their organization perceived maliciously-intended behaviors as more acceptable than their lower-level position counterparts. However, this reverses as communist footprint grows beyond 38.75 years such that individuals at higher level positions in their organization perceived maliciously-intended behaviors as less acceptable than their lower-level position counterparts, also in line with our theoretical predictions.

To further probe the significance of the interaction term in Figure $2 b$, we conducted the change in $\mathrm{R} 2$ and simple slope tests. The change in $\mathrm{R}^{2}$ test noted that a significant portion of the variance in the perceptions of the acceptability of maliciously intended behaviors was increased with the addition of the interaction term $\left(\Delta \mathrm{R}^{2}=0.003, \mathrm{P}<.05\right)$. Once again, position level significantly moderated the effect of communist footprint on perceptions of maliciously intended behaviors, as evidenced by a statistically significant increase in total variation explained of $0.3 \%, F(1,1338)=$ $4.05, \mathrm{p}<.05$. This test suggests that the slopes of the two regression lines for high and low position levels are statistically different. The simple slope test further indicated that for high position individuals, the relationship between communist footprint and maliciously intended behaviors is statistically significant $(p<.055)$ and negative $(-0.017 \pm 0.009)$. For low position individuals, the simple slope test indicated that the relationship between communist footprint and maliciously intended behavior was slightly positive $(0.00005 \pm .007)$ but not significant $(\mathrm{p}=0.994)$. Since the regression coefficient of the interaction term in Table 2 was significant, we conclude that the effect of communist footprint on maliciously intended behaviors depends on position level (D'Angelo et al., 2016; Dawson, 2014).

Overall, we found support for four of our eight hypotheses. Our robustness tests found similar results (see Appendix 2 and Tables A-B). Taken together, these results suggest that earlier subordinate 
influence research that found that communist exposure had no significant overall effect on work influence behavior today had reached premature conclusions as it had not incorporated the length of exposure to communism. Our results show that it is not whether the individual was exposed to communism but for how long that matters for the individual's influence behavior at work today. Nuances in the length of exposure time to communism do affect subordinate influence behaviors significantly, especially at different position levels.

With respect to the direct effect of the communist footprint on subordinate influence behavior, we found that, holding all else constant, the shorter the communist footprint, the less negative professionals are toward organizationally constructive influence behavior at work today. A reason could be that these individuals have more power to contribute positively to their organizations, which is something they were not used to under communism. Contrary to our predictions, we also found that, holding all else constant, the communist footprint had no significant direct effect on organizationally destructive influence behaviors. In statistical terms, this does not mean that the difference between the obtained coefficients and the null hypothesis (i.e., the communist footprint has a zero effect on organizationally destructive behaviors) is nonsignificant. It simply means that the data may not be strong enough to justify full rejection of the null owing to the expected effects and statistical power (Aberson, 2002). One should consider the coefficient's confidence interval (CI) too (Aberson, 2002). The 95\% CIs around the communist footprint coefficients range from -.014 to .002 for the self-serving behaviors, and from -.005 to .007 for the maliciously intended behaviors. Thus, the data are consistent with both the null hypothesis and the communist footprint effect ranging within those CIs (Aberson, 2002). A possible reduction of the self-serving and maliciously-intended behaviors by $1.4 \%$ and $0.5 \%$, respectively, from a one year increase in the communist footprint may be considered too small to be concerned about, but it does not mean they are exactly zero as the null hypothesis states (Aberson, 2002). These results suggest that the effect of communist footprint on the organizationally destructive influence behaviors may be too minimal for a significant concern, so additional research would be necessary to test the generalizability of this finding.

With respect to the moderation effects, we did find that a higher-level position significantly diminishes the hypothesized positive effect of a longer communist footprint on the acceptability of 
organizationally destructive influence behaviors. Thus, individuals with longer communist footprints at higher-level positions in their organization did not approve of organizationally destructive behaviors to the degree that individuals at lower-level positions did. We also found that the position level in the company had no significant moderating effect on the communist footprint for the proorganizational behavior relationship (the $95 \% \mathrm{CI}$ ranged from -.003 to .007 , suggesting the true effect may be too minimal to be concerned about, but not zero, Aberson, 2002). However, position level significantly moderated, albeit in opposite-to-predicted direction, the communist footprint for the image management relationship. This latter finding indicates that individuals with longer communist footprints perceived image management to be less acceptable and even less so if they held higher positions in their companies. Thus, we found three negative and significant moderating effects involving image management, self-serving, and maliciously intended behaviors. The common thread among these three behaviors is the degree of self-interest involved — from lowest in image management to highest in maliciously intended (see Appendix 1). Pro-organizational behavior is the only behavior, which involves the individual caring more for the benefit of the organization rather than his/her own self-interest. These results indicate that individuals with longer communist footprints occupying higher-level positions would not perceive any degree of such self-interest to be acceptable at work today. This may be due to accumulated negative judgments against the exploitations of the communist regime that these individuals endured for a long time.

\section{DISCUSSION}

\section{Theoretical Implications}

We extended imprinting theory in two directions. First, we shifted imprinting theory’s current focus on the discrete communist imprint to the new focus of the continuous communist footprint. To do so, we analyzed how the length of exposure time to communism (the communist footprint) affects the current subordinate influence behavior of communist-socialized individuals. Drawing from fairness heuristic theory, we proposed that this continuous construct captures the varying intensities of fairness judgments about communist authority that individuals formed, depending on how short or prolonged their communist socializations were. As such, the communist footprint concept goes beyond imprinting theory's current focus on the presence or absence of a communist socialization 
through the communist imprint. This is an important extension as it changes the implications of existing subordinate influence behavior research, which has found that the communist imprint has ultimately no significant effect at conventional statistical levels on current influence behavior (Danis et al., 2011). One of our robustness tests confirmed this (see Appendix 2). However, we found that the communist footprint contributes significantly to a more nuanced conceptualization of subordinate influence behaviors. Thus, we integrated the role of history in our understanding of current human behavior, which research has advocated (Ahlstrom, Lamond, and Ding, 2009; Kipping and Usdiken, 2014; Pop-Eleches and Tucker, 2014). More specifically, we elaborated on recent research emphasizing the significance of learning from an important episode in history, in our case- the episode of communism in the former Soviet Union - that had profound effects on and shaped modern human behavior (Ahlstrom, 2014; Hunter, 2013; Peng, 2013).

Accordingly, we urge future individual-level research drawing on imprinting theory to differentiate the discrete communist imprint from the continuous communist footprint when studying individuals' socialization for proper research implications. As we proposed and showed, the imprint approach is problematic when analyzing individuals' socialization under a key historical period because it relies on the sweeping assumption that all communist-socialized individuals were indoctrinated with the same intensity of communist ideology. Drawing from fairness heuristic theory, we showed that this is an inaccurate assumption, as it ignores individuals' intensity of accrued resentment toward authority during communism, as more aptly captured by the communist footprint. Because the length of exposure time to communism is a process that unfolds during the individual's socialization, the communist footprint concept is better suited to capture the inherent individual-level heterogeneities during this process.

Second, we answered recent calls for a more nuanced understanding of whether initial imprints are weaker for some individuals than for others (Simsek et al., 2015). We took this call a step further and analyzed whether the communist footprint is stronger for some individuals than for others, and if so, under what contexts. We proposed that an individual's position level in the company can modify the baseline relationships between the communist footprint and influence behaviors at work today. In so doing, we offered a more nuanced perspective showing that the effect of initial exposure 
to historical socializations can be attenuated depending on different situational contexts. Thus, while imprinting research has perceived imprinted individuals as passive carriers of said imprints (Simsek et al., 2015), we instead proposed and found that individuals can and do have power over controlling to what extent their earlier socialization exposures affect their present-day work behaviors. Prior imprinting research has considered factors such as path dependence processes, homophily, performance feedbacks, or best practice imitation as possible modifiers of the intensity of initial imprints (Simsek et al., 2015). Yet, our study was the first to integrate insights from fairness heuristic theory (Bobocel, 2013; van de Ven, 1997a, b) to show under what conditions fairness judgments can be weaker for some individuals and stronger for others. Specifically, a situational factor such as position level in the company can modify the intensity of individuals' fairness judgments accumulated during life under communist authority. The integration of imprinting theory with fairness heuristic theory allowed us to show that the communist footprint has not only a direct effect on individuals but also an indirect effect through the influence of position level in the company. Thus, we answered calls for more studies on such indirect imprinting effects, in our context—indirect footprint effects, to extend current imprinting theory (Simsek et al., 2015). In sum, we believe our communist footprint perspective helps add greater depth of conceptualization in current imprinting theory when applied to individual-level phenomena such as communist socialization and influence behaviors.

\section{Managerial Implications}

Our research provides interesting implications for communist-socialized professionals and for managers and firms responsible for these individuals. Overall, our results showed that organizations should realize that unconventional approaches might be needed to alleviate the resentment that communist-socialized subordinates with longer communist footprints may harbor toward unfair authority. Training workshops can help clarify the range of acceptable influence behaviors at work (Pucetaite and Lamsa, 2008).

We also found that individuals with a longer communist footprint at higher-level positions perceive organizationally destructive behaviors, including image management, as unacceptable. This is interesting as it shows that individuals with longer communist footprints at higher-level positions are more likely to be paternalistic and protective of their organizations and far less likely to follow 
only their own self-interest than previously thought. Thus, companies should avoid negative stereotyping against such longer communist-exposed individuals and, instead, provide them with opportunities to allow them to demonstrate of what they are capable, once the burden of the unfair communist authority is no longer hanging on their shoulders. It is because these individuals experienced first-hand and for prolonged time the unfair practices of communist authority that they seek to avoid subjecting others to such negative experiences today.

\section{Limitations and Future Research}

First, our paper used the terms 'perceptions of acceptable behavior' and 'behavior' interchangeably for brevity of exposition. However, we note that our questionnaire focused specifically on individuals' perceptions of acceptable behaviors at their organizations. We used this other-report technique to avoid key problems of self-report measures such as distortion of their true responses to hide personal insecurities or protect self-image (Anastasi, 1982). This approach is also common in studies in other disciplines (e.g., political economy), which seek responders' views on sensitive topics such as corruption (Martin et al., 2007). For example, a similarly-framed other-report question from the World Bank corruption surveys is: "Thinking now of unofficial payments/gifts that a firm such as yours would make in a given year, could you please tell me how often would they make payments/gifts for the following purposes" (Business Environment and Enterprise Survey, 2005). Other-report measures focus the responders' attention on the typical behavior of their co-workers, thus reducing the responder's need to be defensive and/or secretive in his/her responses. At the same time, a key caveat of our study is that we are not able to capture responders' personal behavior directly but simply the responders' perceptions of whether their co-workers would consider different influence behaviors acceptable or not at work today. Both self-report and other-report questionnaires have response biases but the latter minimizes them. Self-report measures are associated with six response biases (acquiescence; disacquiescence; carelessness; extreme, midpoint, and sociallydesirable response styles), while other-report measures are associated with two (halo and leniency effects) (Wetzel, Bohnke, and Brown, 2016). Halo and leniency effects are more prevalent in performance appraisal studies (Riggio, 2013), which is not our focus. Thus, our results are less likely to be affected by such halo/leniency bias effects. 
Second, although our questionnaire design has satisfied many of the best practices in crosscultural design guidelines such as using a derived-etic approach, alignment of the research contexts, theoretical reason for country inclusion, and semantic equivalence (Samiee and Jeong, 2004; Schaffer and Riordan, 2003), further finer-grained procedures can be useful. For instance, possible sub-cultural differences can be more explicitly incorporated into the theoretical framework instead of being treated as constant (Schaffer and Riordan, 2003). Other forms of translations can also be used such as pragmatic, linguistic, aesthetic-poetic, and ethnographic to improve unidimensionality (Samiee and Jeong, 2004). Although we used an 8-point Likert scale rather than the typical U.S.-centric 5-point one, future studies could use an even larger number of Likert dimensions (Schaffer and Riordan, 2003).

Third, our study is cross-sectional, as is prior survey research on subordinate influence behavior (e.g., Danis et al., 2011; Karam et al., 2013; Ralston et al., 2009, 2013). Future research can extend ours by analyzing possible changes in the subordinates' influence behavior over time with longitudinal data in both post-communist transition economies and existing communist economies, such as China, Cuba and Vietnam (Ahlstrom, Bruton, and Yeh, 2008). Our cross-sectional study furthers our knowledge of influence behavior at work by finding that historical time can significantly change the predictions of theoretical frameworks, which is in line with previous research in other areas (Zaheer et al., 1999).

Fourth, our study focused only on subordinate influence behaviors. There are additional types of influence behaviors such as those that superiors use to influence their subordinates or those that peers use to influence each other (Falbe and Yukl, 1992). Future research could study the effect of the communist footprint on such downward and lateral influence behaviors. Nonetheless, given the autocratic nature of the communist system, we believe that the informal subordinate influence behaviors are the ones most relevant to understand the dynamics of influence behavior in postcommunist transition economies.

Fifth, our study focused on the acceptance of different types of subordinate influence behaviors, ranging from organizationally constructive to organizationally destructive. Data availability precluded us from being able to tell how successful these behaviors were for the 
professionals in actually influencing their superiors. Thus, future research could analyze the effectiveness of different types of behavior for different types of professionals depending on the length of their communist footprint.

Sixth, our study focused on a key situational factor-position level in the company. Future research can also explore other situational factors like, e.g., an organization's policy, climate, team culture, etc. for which, unfortunately, we did not have data but which can further shape individual expectations and roles. Additionally, it may be possible that those with the proper 'characteristics' or values are the one who get promoted and it is because of these features that these individuals are both different from the lower-level employees and were, hence, promoted. As this was beyond the scope of our study's intentions, we do not have unfortunately such finer-grained data to test this possibility. Thus, future research can also extend ours and explore these interesting possibilities in further depth. Seventh, we also followed recent calls in the imprinting literature to control for contemporaneous imprints (Simsek et al., 2015) by including, e.g., the individuals' reform footprint as a control variable. We found that reform footprint significantly affects image management and maliciously intended influence behaviors. This suggests the interesting possibility that the individuals may have been re-imprinted by market capitalism and carry this reform footprint in addition to their initial communist footprint. Beyond some recent firm-level entrepreneurship research on the notion of re-imprinting (Ferriani et al., 2012), we are not aware of individual-level research on the topic to which we could compare this finding. Future research should probe this possibility further.

Eighth, the communist footprint is but one example of the larger theme of how history affects current human behavior (Coraiola et al., 2015; Kipping and Usdiken, 2014; Pop-Eleches and Tucker, 2014). Our significant finding of a past period effect on current perceptions of human behavior indicates that, fundamentally, it might be generalized beyond the communist experience of transition economies. The impacts of other historical periods (e.g., war, colonial heritage, catastrophic natural disaster, or political upheaval) on present-day human behavior are interesting new venues for future investigation. For example, research has shown that both the First and Second World War left an indelible mark on the creation of modern-day business and HR practices (Ahlstrom, 2014) as did the historical episode of the $19^{\text {th }}$ century intellectual property rights protection dispute between the U.S., 
Great Britain, and China (Peng, 2013; Peng, Ahlstrom, ). Thus, our study helps provide first steps toward a better understanding of not just the institutional context of a region, but also the broader historical context (Ahlstrom, 2014; Peng, 2013). This understanding helps us to avoid the problem of snapshots of complex systems that may be misleading (Peng, Ahlstrom, Carraher, \& Shi, 2017), as well as avoiding the problem of an episodic or somewhat superficial use of history or historical context (Ahlstrom et al., 2009; Hunter, 2013; Lohrke, Ahlstrom, Bruton, 2012).

\section{CONCLUSION}

The effect of the communist footprint is still being felt in subordinate behaviors at work today even decades after the fall of communism, though not entirely in the way that we had expected. Specifically, our study analyzed how the length of exposure to a specific historical episode, that is, communism in the former Soviet Union's satelite states, affects the subordinate influence practices of business professionals from seven transition economies at work today. We focused on how this communist footprint affects two types of influence behaviors: organizationally constructive (proorganizational and image management) and organizationally destructive (self-serving and maliciously intended). We also theorized and demonstrated that one's position in the organization further moderates the communist footprint-influence behaviors at work relationships. We proposed and found that the shorter the communist footprint, the less negative professionals are toward organizationally constructive influence behavior at work today, holding all else constant, owing to these individuals' shorter experience with fending for themselves during communism. We further proposed and found that individuals with longer communist footprints at higher-level positions in their organization did not approve of organizationally destructive behaviors to the degree that individuals at lower-level positions did, owing to the former's higher sense of paternalistic responsibility toward their subordinates and organizations. Conversely, we found that with the increased time spent living in the communist society, and contrary to our predictions, the communist footprint had no significant direct effect on organizationally destructive influence behaviors. This may be due in part to the smaller hypothesized effect size and statistical power of the study, which did not allow a finer-grained analysis of the data. We thus showed that by utlizing the length of time of the communist footprint in 
the study likely provides a better understanding of work behaviors today than a simple present or not dichotomy with respect to a communist imprint that had been the focus of prior imprinting research.

In conclusion, this paper has extended imprinting theory with insights from fairness heuristic theory to account for an individual's length of communist socialization and its effect on influence behaviors at work today. Our theoretical extensions unveiled heterogeneities among the perceptions of acceptable work behaviors of communist-socialized individuals, which have not been well understood to date in the international management literature. We further developed conditions under which these heterogeneities in individual perceptions are more or less pronounced depending on the individuals' position in the company. Although we tested the concept of footprint length in the specific context of communist exposure, we hope our study is a first step toward generalizing our research to interesting new avenues such as how the length of individuals' exposure to different historical episodes in a country affect current management practices. Our study thus joins recent research that has begun guiding the field in this direction: "[t]he First World War was a terrible tragedy that has left an indelible mark on the geopolitical landscape. But in the process, it spurred major changes in business that have helped to create the modern world" (Ahlstrom, 2014: 218). It might similarly be said that the communist regime that was present for so long in the countries of Central and Eastern Europe also left an indelible mark on individual identity that countries and firms are still struggling to sort out more than a quarter century after the fall of the Berlin Wall. 


\section{REFERENCES}

Aberson, C. (2002). Interpreting null results: Improving presentation and conclusions with confidence intervals. JASNH, 1(3): 36-42. Available online at http://www.jasnh.com/a6.htm.

Ahearne, M., Lam., S., and Kraus, F. (2014). Performance impact of middle managers' adaptive strategy implementation: the role of social capital, Strategic Management Journal, 35: 68-87.

Ahlstrom, D. (2014). The hidden reason why the First World War matters today: The development and spread of modern management. Brown Journal of World Affairs, 21(1), 201-218.

Ahlstrom, D., Bruton, G. D., and Yeh, K. S. (2008). Private firms in China: building legitimacy in an emerging economy, Journal of World Business, 43(4): 385-399.

Ahlstrom, D., Lamond, D., and Ding, Z. (2009). Reexamining some management lessons from military history. Asia Pacific Journal of Management, 26(4): 617-642.

Ahlstrom, D., Young, M. N., Nair, A., and Law, P. (2003). Managing the institutional environment: Challenges for foreign firms in post WTO China. SAM Advanced Management Journal, 68(2), 41-49.

Aiken, L. S., and West, S. G. (1991). Multiple Regression: Testing and Interpreting Interactions. Newbury Park: Sage.

Alas, R. and Rees, C. (2006). Work-related attitudes, values and radical change in post-communist contexts: A comparative study. Journal of Business Ethics, 68, 181-189.

Anastasi, A. (1982). Psychological Testing (2nd ed.). MacMillan: New York.

Aquino, K., Tripp, T. M., \& Bies, R. J. (2006). Getting even or moving on? Power, procedural justice, and types of offenses as predictors of revenge, forgiveness, reconciliation, and avoidance in organizations. Journal of Applied Psychology, 91, 653-668.

Applebaum, A. (2003). Gulag: A History. New York: Doubleday.

Berry, J.W. (1979). A cultural ecology of social behavior. In L. Berkowitz (Ed.), Advances in Experimental Social Psychology (Vol. 12, pp. 177-206). New York: Academic Press.

Blanchflower, D. and Freeman, R. (1997). The attitudinal legacy of communist labor relations. Industrial and Labor Relations Review, 50(3), 438-459.

Bobocel, D. (2013). Coping with unfair events constructively or destructively: the effects of overall justice and self-other orientation. Journal of Applied Psychology, 98(5), 720-731.

Boobbyer, P. (2005). Conscience, dissent, and reform in Soviet Russia, Routledge Taylor and Francis Group: London and New York.

Boyle, G. J. (1991). Does item homogeneity indicate internal consistency or item redundancy in psychometric scales? Personality and Individual Differences, 12(March): 291-294.

Brambor, T., Clark, W., and Golder, M. (2006). Understanding interaction models: improving empirical analyses, Political Analysis, 14: 63-82.

Bruton, G. and Lau, M-C. (2008). Asian management research: status today and future outlook. Journal of Management Studies, 45(3): 637-659.

Business Environment and Enterprise Survey. (2005). http://data.worldbank.org/data-catalog/BEEPS

Caprar, D. and Budean, A. (2013). Manager-subordinate trust relationships in Romania. In Cardona, P. and Morley, M. J. (Ed.), Manager-subordinate Trust. A Global Perspective. Routledge: London and New York, 117-136.

Chari, M. and Banalieva, E.R. (2015). How do pro-market reforms impact firm profitability? The case of India under reform. Journal of World Business, 50(2): 357-367.

Chen, C. (2014). Are workers more likely to be deviant than managers? A cross-national analysis. Journal of Business Ethics, 123: 221-233.

Cheng, J., Birkinshaw, J., Lessard, D., and Thomas, D. (2014). Advancing interdisciplinary research: insights from the JIBS special issue. Journal of International Business Studies, 45, 643-648.

Chiaburu, D., and Lim, A. (2007). Manager trustworthiness or interactional justice? Predicting organizational citizenship behaviors. Journal of Business Ethics, 83: 453-467.

Christensen, P. T. (1999). Russia's workers in transition: Labor, management, and the State under Gorbachev and Yeltsin. DeKalb, IL: University of Northern Illinois Press.

Christmann, P. (2000). Effects of "best practices" of environmental management on cost advantage: the role of complementary assets. Academy of Management Journal, 43(4), 663-680.

Cialdini, R. B. (2006). Influence: The psychology of persuasion. New York: Harper Business. 
Clarke, P. (2008). When can group level clustering be ignored? Multilevel models versus single-level models with sparse data. Journal of Epidemiology and Community Health, 62, 752-758.

Cooke, B. (2003). The denial of slavery in management studies. Journal of Management Studies, 40(8), 1895-1918.

Coraiola, D., Foster, W., and Suddaby, R. (2015). Varieties of history in organization studies. In Kerr, C. (Ed.), The Routledge Companion to Management and Organizational History.

Danis, W., Liu, L., and Vacek, J. (2011). Values and upward influence strategies in transition: evidence from the Czech Republic. Journal of Cross-Cultural Psychology, 42(2), 288-306.

Dawson, J. F. (2014). Moderation in management research: What, why, when, and how. Journal of Business Psychology. 29(1), 1-19. http://dx.doi.org/10.1007/s10869-013-9308-7

D’Angelo, A., Majocchi, A., and Buck, T. (2016). External managers, family ownership and the scope of SME internationalization. Journal of World Business, http://dx.doi.org/10.1016/j.jwb.2016.01.004

de Melo, M., Denizer, C., Gelb, A., and Tenev, S. (1997). Circumstance and Choice: The Role of Initial Conditions and Policies in Transition Economies. Policy Research Working Paper, WPS 1866, The World Bank Development Research Group. Available at: http://elibrary.worldbank.org/doi/abs/10.1596/1813-9450-1866 (accessed 3 August 2015).

Dekas, K. and Baker, W. (2014). Adolescent socialization and the development of adult work orientations, In H. Grieve and M-D. Seidl (eds.) Adolescent Experiences and Adult Work Outcomes: Connections and Causes, Emerald Group Publishing: UK.

Dulebohn, J., Bommer, W., Liden, R., Brouer, R., and Ferris, G. (2012). A meta-analysis of antecedents and consequences of leader-member exchange: integrating the past with an eye toward the future. Journal of Management, 38(6), 1715-1759.

Dutton, J., and Ashford, S. (1993). Selling issues to top management, Academy of Management Review, 18(3): 397-428.

Dutton, J., Ashford, S., O’Neil, R., Hayes, E., and Wierba, E. (1997). Reading the wind: how middle managers assess the context for selling issues to top managers, Strategic Management Journal, 18(5): 407-425.

Egri, C., and Ralston, D. (2004). General cohorts and personal values: a comparison of China and the United States. Organization Science, 15(2), 210-220.

Egri, C., Ralston, D., Murray, C., and Nicholson, J. (2000). Managers in the NAFTA countries: a cross-cultural comparison of attitudes towards upward influence strategies. Journal of International Management, 6, 149-172.

Falbe, C. and Yukl, G. (1992). Consequences for managers of using single influence tactics and combinations of tactics. Academy of Management Journal, 35, 638-652.

Falcetti, E., Raiser, M., and Sanfey, P. (2002). Defying the odds: initial conditions, reforms, and growth in the first decade of transition. Journal of Comparative Economics, 30, 229-250.

Ferriani, S., Garnsey, E., and Lorenzoni, G. 2012. Continuity and change in a spin-off venture: the process of reimprinting, Industrial and Corporate Change, 21(4): 1011-1048.

Fields, D. (2002). Taking the measure of work: a guide to validated scales for organizational research and diagnosis, Sage Publications: Thousand Oaks, CA.

Fitzpatrick, S. (1999). Everyday Stalinism. Ordinary Life in Extraordinary Times: Soviet Russia in the 1930s. New York: Oxford University Press.

Floyd, S.W., and Wooldridge, B. (1994). Dinosaurs of dynamos? Recognizing middle managers, Academy of Management Executive, 8 (4): 47-57.

Fortin, M., Cojuharenco, I., Patient, D., and German, H. (2014). It is time for justice: how time changes what we know about justice judgments and justice effects, Journal of Organizational Behavior, doi: 10.1002/job.1958.

$\mathrm{Fu}, \mathrm{P}$. and Yukl, G. (2000). Perceived effectiveness and use of influence tactics in the US and China. Leadership Quarterly, 11(2), 251-266.

Gormley, T. and Matsa, D. (2014). Common errors: How to (and not to) control for unobserved heterogeneity, The Review of Financial Studies, 27(2): 617-661.

Harris, Z. (1997). The transformation of capitalist society, Rowman and Littlefield Publishers, Lanham, Maryland.

Harzing, A. W. (1997). Response rates in international mail surveys: results of a 22 country study. International Business Review, 6(6), 641-665. 
Henson, R.K. (2001). Understanding internal consistency reliability estimates: A conceptual primer on coefficient alpha. Measurement and Evaluation in Counseling and Development, 34 (3), 177-189.

Hernández-Catá, E. (1998). Consumer prices, money supply, and liberalization in post-communist economies. Cuba in Transition, Association for the Study of Cuban Economy, 8, 291-301.

Holmes, K. R., Feulner, E. J., and O'Grady, M. A. (2008). 2008 Index of Economic Freedom. The Heritage Foundation, Washington D.C. and The Wall Street Journal, New York.

Hoskisson, R., Eden, L., Lau, C., and Wright, M. (2000). Strategy in emerging economies. Academy of Management Journal, 43, 249-267.

Hoskisson, R., Johnson, R., Tihanyi, L., and White, R. (2005). Diversified business groups and corporate refocusing in emerging markets. Journal of Management, 31, 941-965.

Hunter, M. (2013). History lessons for the 21 st-century classroom. Standpoint, January/February: 5055.

Hurt, M., Hurt-Warski, S., and Roux-Dufort, C. (2000). Herbapol Lublin: A Polish Company Privatizes and Learns To Do Business in a Market Economy. Teaching note, reference no. 300-141-1, EDHEC School of Management.

Jaffe, E. and Tsimerman, A. (2005). Business ethics in a transition economy: Will the next Russian generation be any better? Journal of Business Ethics, 62: 87-97.

Johns, G. (2006). The essential impact of context on organizational behavior. Academy of Management Review, 31(2): 386-408.

Johnson S, Kaufmann D, McMillan J, Woodruff, C. 2000. Why do firms hide? Bribes and unofficial activity after communism. Journal of Public Economics 76: 495-520.

Jones, D. and Skarlicki, D. (2013). How perceptions of fairness can change: a dynamic model of organizational justice. Organizational Psychology Review, 3(2), 138-160.

Karam, C. M., Ralston, D. A., Egri, C. P., Butt, A., Srinivasan, N., Fu, P. P., Lee, C. H., Moon, Y. L., Li, Y., Ansari, M., Kuo, M. H., Thanh, H. V., Pekerti, A., Hallinger, P., Fang, Y., and Chia, H. B. (2013). The use of favors to get ahead at work in Asia: an 11-society assessment. AsiaPacific Journal of Management, 30, 373-408.

Kipping, M. and Usdiken, B. (2014). History in organization and management theory: more than meets the eye. The Academy of Management Annals, 8(1), 535-588.

Kornai J. 2000. What the change of system from socialism to capitalism does and does not mean. Journal of Economic Perspectives 14(1): 27-42.

Kozlowski, S. W. J., \& Klein, K. J. 2000. A multilevel approach to theory and research in organizations: Contextual, temporal, and emergent processes. In K. J. Klein \& S. W. J. Koslowski (Eds.) ,Multilevel theory, research, and methods in organizations:3-90. San Francisco: Jossey-Bass

Kuratko, D., and Goldsby, M. (2004). Corporate entrepreneurs or rogue middle managers? A framework for ethical corporate entrepreneurship, Journal of Business Ethics, 55: 13-30.

Laszkiewicz, E. (2013). Sample size and structure for multilevel modeling: Monte Carlo investigation for the balanced design. Quantitative Methods in Economics, XIV(2), 19-28.

Lewin, K. (1951). .Field theory in social science: Selected theoretical papers. (Edited by D. Cartwright.) New York: Harper \& Row.

Lind, E. A. (2001). Fairness heuristic theory: Justice judgments as pivotal cognitions in organizational relations. In J. Greenberg \& R. Cropanzano (Eds.), Advances in organizational justice (pp. 5688). Lexington, MA: New Lexington.

Lind, E. and van den Bos, K. (2002). When fairness works: toward a general theory of uncertainty management. Research in Organizational Behavior, 24, 181-223.

Lane, D. (2014). The Capitalist Transformation of State Socialism: The Making and Breaking of State Communist Society and what Followed. New York: Routledge.

Liden, R. and Mitchell, T. (1988). Ingratiatory behaviors in organizational settings. Academy of Management Review, 13(4), 572-587.

Linz, S. and Chu, Y, (2013). Work ethic in formerly socialist economies, Journal of Economic Psychology, 39: 185-203. 
Lohrke, F. T., Ahlstrom, D., \& Bruton, G. D. (2012). Extending turnaround process research: Important lessons from the US Civil War. Journal of Management Inquiry, 21(2), 217-234.

Mannheim, K. (1952). (First published in 1928). The problem of generations. In Mannheim, K. (Ed.), Essays on the Sociology of Knowledge. London: Routledge, 276-322.

Marshall, M., Jaggers, K., and Gurr, T. (2011). Polity IV Project: Dataset Users' Manual. Center for Global Policy, School of Public Policy, George Mason University and Center for Systemic Peace: Fairfax County, VA, and Vienna, VA.

Martin, K., Cullen, J., Johnson, J., and Parboteeah, K. (2007). Deciding to bribe: A cross-level analysis of firm and home country influences on bribery activity. Academy of Management Journal, 50, 1401-1422.

Maxwell, B. (1996). Translation and cultural adaptation of the survey instruments. In Martin, M. O. and Kelly, D. L. (Eds.), Third International Mathematics and Science Study (TIMSS) Technical Report, Volume I: Design and Development. Chestnut Hill, MA: Boston College.

McCarthy, D. and Puffer, S. (2008). Interpreting the ethicality of corporate governance decisions in Russia: utilizing integrative social contracts theory to evaluate the relevance of agency theory norms. Academy of Management Review, 33(1): 11-31.

Meyer, K. E., Estrin, S., Bhaumik, S. K. \& Peng, M. W. 2009. Institutions, resources, and entry strategies in emerging economies. Strategic Management Journal, 30(1): 61-80.

Miller, D. J., Giacobbe-Miller, J. K. and Zhang, W. (1999). A Comparative Study of Chinese and U.S. Distributive Justice Values, Goals and Allocative Behaviors, in J. Cheng and R. Peterson (eds.), Advances in International Comparative Management (JAI Press, Stamford, CT).

Morris, M. W., Leung, K., Ames, D., and Lickel, B. (1999). Views from inside and outside: Integrating emic and etic insights about culture and justice judgment. Academy of Management Review, 24(4), 781-796.

Morison, R., Erickson, TJ, and Dychtwald, K (2006). Managing middlescence. Harvard Business Review, 84(3): 78-86.

Mowday, R. T., \& Sutton, R. I. (1993). Organizational behavior: Linking individuals and groups to organizational con-texts. Annual Review of Psychology,44: 195-229.

Mutlu, C. C., Zhan, W., Peng, M. W., and Lin, Z. J. (2015). Competing in (and out of) transition economies. Asia Pacific Journal of Management, 32(3), 571-596.

Nadkarni, S. and Barr, P. (2008). Environmental context, managerial cognition, and strategic action: an integrated view. Strategic Management Journal, 29, 1395-1427.

Napier, N. and Thomas, D. (2004). Managing Relationships in Transition Economies. Westport: Praeger Publishers.

Neugeboren, B. (1991). Organization, policy, and practice in the human services. New York: Routledge.

Niehaus, E., Campbell, C., and Inkelas, K. (2014). HLM behind the curtain: unveiling decisions behind the use and interpretation of HLM in higher education research. Research in Higher Education, 55(1), 101-122.

Nunnally, J. (1967). Psychometric Theory, New York: McGraw-Hill.

Pearce, J. (1991). From socialism to capitalism: the effects of Hungarian human resources practices. The Executive, 5(4), 75-88.

Peng, M. W. (2013). An institution-based view of IPR protection. Business Horizons, 56(2), 135-139.

Peng, M. W., Ahlstrom, D., Carraher, S. M., \& Shi, W. (2017). An institution-based view of global IPR history. Journal of International Business Studies, forthcoming.

Peter, L. and O'Connor, E. (1980). Situational constraints and work outcomes: The influences of a frequently overlooked construct. Academy of Management Review, 5(3): 391-397.

Podsakoff, P., MacKenzie, S., Paine, J., and Bachrach, D. (2000). Organizational citizenship behaviors: a critical review of the theoretical and empirical literature and suggestions for future research. Journal of Management, 26(3), 512-563.

Podsakoff, P.M., and Organ, D. (1986). Self-reports in organizational research: problems and prospects. Journal of Management, 12(4), 531-544.

Pop-Eleches, G. and Tucker, G. (2014). Communist socialization and post-communist economic and political attitudes. Electoral Studies, 33, 77-89. 
Pratt, M., and Rafaeli, A. (1997). Organizational dress as a symbol of multilayered social identities, Academy of Management Journal, 409: 862-898.

Pucetaite, R. and Lamsa, A. (2008). Developing organizational trust through advancement of employees' work ethic in a post-communist context. Journal of Business Ethics, 82, 323-337.

Puffer, S. (1993). A riddle wrapped in an enigma: demystifying Russian managerial motivation. European Management Journal, 11(4), 473-480.

Puffer, S. (1994). Understanding the bear: a portrait of Russian business leaders. Academy of Management Executive, 8(1), 41-54.

Puffer, S. and McCarthy, D. (2003). Corporate governance in transitioning economies, Journal of World Business, 38(4): 281-283.

Puffer, S., McCarthy, D., and Naumov, A. (1997). Russian managers' beliefs about work: beyond the stereotypes, Journal of World Business, 32(3): 258-276.

Ralston, D. and Pearson, A. (2010). The cross-cultural evolution of the subordinate influence ethics measure. Journal of Business Ethics, 91, 149-168.

Ralston, D. A., Egri, C. P., de la Garza-Carranza, M. T., Ramburuth, P., Terpstra-Tong, J., Pekerti, A., Grison, I., Herrig, H., Dabic, M., Tang, M., Wan, P., Hallinger, P., Palmer, I., Elenkov, D., Furrer, O., Potocan, V.V., Wangenheim, F., Maignan, I., Perrewé, P., Rossi, A. M., Lenartowicz, T., Ledgerwood, D. E., May, R. C., Weber, M., Jesuino, J. C., Fu, P. P., Naoumova, I., Casado, T., Riddel, L., Richards, M., Butt, A., Danis, W., Castro, F. B., RuizGutiérrez, J. Milton, L., Ansari, M., Brock, D., Srinivasan, N., Starkus, A., Dalgic, T., Darder, F. L., Hung, V. T., Moon, Y. L., Chia, H. B., Kuo, C., Molteni, M., Kangasniemi, M., Mellahi, K., and Wallace, A. (2009). Ethical preferences for influencing superiors: a 41-society study. Journal of International Business Studies, 40(6), 1022-1045.

Ralston, D. A., Egri, C. P., Furrer, O., Kuo, M-H., Li, J., Wangenheim, F., Dabic, M., Naoumova, I., Shimizu, K., de la Garza Carranza, M. T., Fu, P. P., Potocan, V., Pekerti, A., Lenartowicz, T., Srinivasan, N., Casado, T., Rossi, A. M., Szabo, E., Butt, A., Palmer, I., Ramburuth, P., Brock, D., Terpstra-Tong, J., Grison, I., Reynaud, E., Richards, M., Hallinger, P., Castro, F. B., Gutiérrez, J. R., Milton, L., Ansari, M., Starkus, A., Mockaitis, A., Dalgic, T., Darder, F. L., Thanh, H. V., Moon, Y-L., Molteni, M., Fang, Y., Pla-Barber, J., Alas, R., Maignan, I., Jesuino, J. C., Lee, C-H., Nicholson, J. D., Chia, H-B., Danis, W., Dharmasiri, A. S., and Weber, M. (2013). Societal-level versus individual-level predictions of ethical behavior: A 48society study of collectivism and individualism. Journal of Business Ethics, 122(2): 283-306.

Raudenbush, S. W. and Bryk, A. S. (2002). Hierarchical Linear Models: Applications and Data Analysis Methods. Newbury Park: Sage.

Riggio, R. (2013). Introduction to Industrial/Organizational Psychology, Routledge Taylor and Francis Group: London and New York.

Ryan, L. (2006). Current ethical issues in Polish HRM, Journal of Business Ethics, 66: 273-290.

Samiee, S., and Jeong, I. (2004). Cross-cultural research in advertizing: An assessment of methodologies, Journal of the Academy of Marketing Science, Summer: 205-217.

Rousseau, D.M., \& Fried, Y. (2001). Location, location, location: Contextualizing organizational research. Journal of Organizational Behavior, 22: 1-13.

Schaffer, B., and Riordan, C. (2003). A review of cross-cultural methodologies for organizational research: a best practices approach, Organizational Research Methods, 6(2): 169-215.

Schwartz, S. and Bardi, A. (1997). Influences of adaptation to Communist rule on value priorities in Eastern Europe. Political Psychology, 18(2), 385-410.

Sexty, R. (1998). Teaching business ethics in transitional economies: avoiding ethical missionary, Journal of Business Ethics, 17: 1311-1317.

Simsek, Z., Fox, B., and Heavy, C. (2015). "What's past is prologue": A framework, review, and future directions for organizational research on imprinting, Journal of Management, 41(1): 288-317.

Siu, N., and Lam, K-C. (2008). A comparative study of ethical perceptions of managers and nonmanagers, Journal of Business Ethics, 88: 167-183.

Stinchcombe, A. (1965). Social structure and organizations. In March, J. G. (Ed.), Handbook of Organizations. Chicago: Rand McNally and Co, 142-193. 
Trevino, L., Weaver, G., and Brown, M. (2008). It's lovely at the top: hierarchical levels, identities, and perceptions of organizational ethics, Business Ethics Quarterly, 18(2): 233-252.

Trianidis, H., Chen, C. X. P. and Darius, K. (1998). Scenarios for the measurement of collectivism and individualism, Journal of Cross-Cultural Psychology, 29, 275-290.

Tripp, T., Bies, R., and Aquino, K. (2007). A vigilante model of justice: revenge, reconciliation, forgiveness, and avoidance, Social Justice Research, 20(1): 10-34.

Tsoukas, H. (1994). Socio-economic systems and organizational management: an institutional perspective on the Communist firm. Organization Studies, 15(1), 21-45.

Tsui, A. (1984). A role set analysis of managerial reputation. Organizational Behavior and Human Performance, 34(1): 64-96.

Tverdohleb, E. (2012). The institutional change in action: transitioning to economic man. Communist and Post-Communist Studies, 45, 363-373.

Uslaner, E. and Badescu, G. (2004). Honesty, trust, and legal norms in the transition to democracy: why Bo Rothstein is better able to explain Sweden than Romania. In Kornai, J., Rothstein, B., and Rose-Ackerman, S. (Ed.), Creating Social Trust in Post-Socialist Transition. New York and New England: Palgrave McMillan.

van den Bos, K., Lind, E., and Wilke, H. (1997a). How do I judge my outcome when I do not know the outcome of others? The psychology of the fair process effect. Journal of Personality and Social Psychology, 72(5), 1034-1046.

van den Bos, K., Vermunt, R., and Wilke, H. (1997b). Procedural and distributive justice: what is fair depends more on what comes first than on what comes next. Journal of Personality and Social Psychology, 72(1), 95-104.

van Dijke, M., Cremer, D., and Mayer, D. (2010). The role of authority power in explaining procedural fairness effects. Journal of Applied Psychology, 95(3), 488-502.

Veiga, J., Yanouzas, J., and Buchholtz, A. (1995). Emerging cultural values among Russian managers: What will tomorrow bring? Business Horizons, 38(4): 20-27.

Vogel, E. (1972) Canton under Communism: Program and politics in a provincial capital, 1949-68. New York: Joanna Cotler Books.

Wetzel, E., Bohnke, J., and Brown, A. (2016). Response biases. In F. Leong, D. Bartram, F. Cheung, K. Geisinger, and D. Iliescu (eds.) The ITC International Handbook of Testing and Assessment, Oxford University Press.

Yang, J., Zhang, Z-X., and Tsui, A. (2010). Middle manager leadership and frontline employee performance: bypass, cascading, and moderating effects. Journal of Management Studies, 47(4): 654-678.

Zaheer, S., Albert, S., and Zaheer, A. (1999). Time scales and organizational theory. Academy of Management Review, 24(4), 725-741. 
Figure 1. A stylized illustration of the conceptual distinction between the communist imprint and the communist footprint

Panel A: The Communist Imprint *

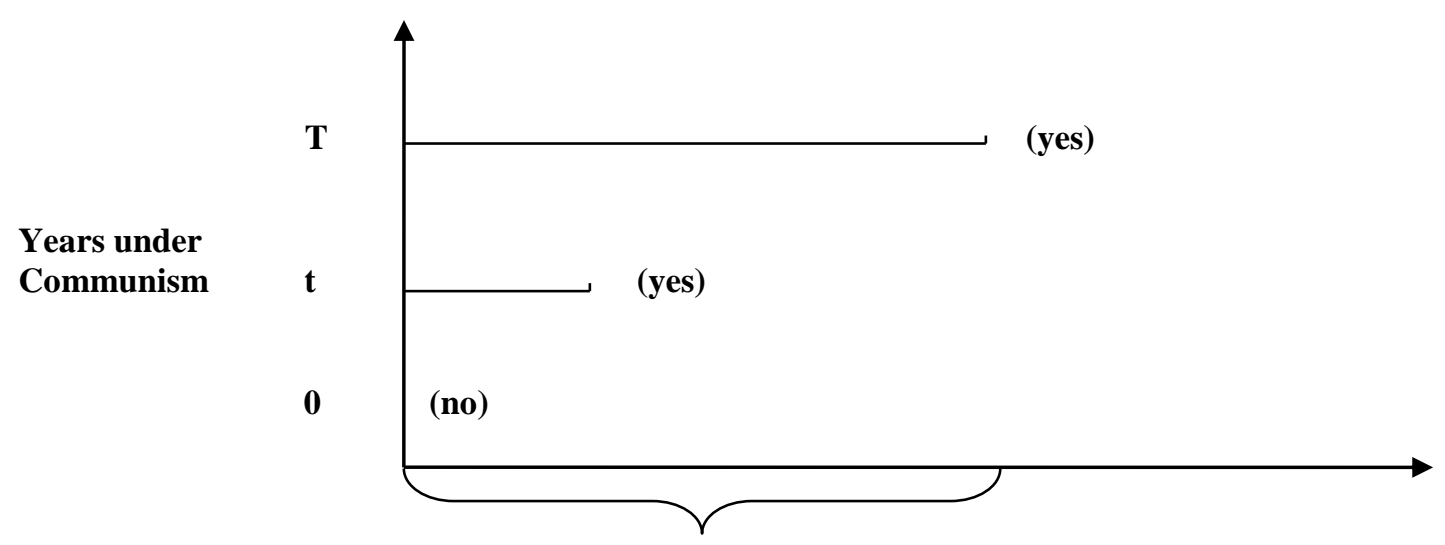

\section{Communist Imprint (yes/no)}

*NOTE: $t$ and T present two theoretical cases for the number of years an individual has been exposed to communism since birth. The length of the horizontal lines indicates the length of exposure to communism. An individual born after the start of market liberalization (case 0 ) receives a "no" due to having no prior exposure to communism. Two individuals born before the start of market liberalization but one's birth year is closer to the start of market liberalization (case t) than the other's (case T). Both receive a "yes" as the communist imprint perspectives treats them the same.

Panel B: The Length of Communist Footprint *

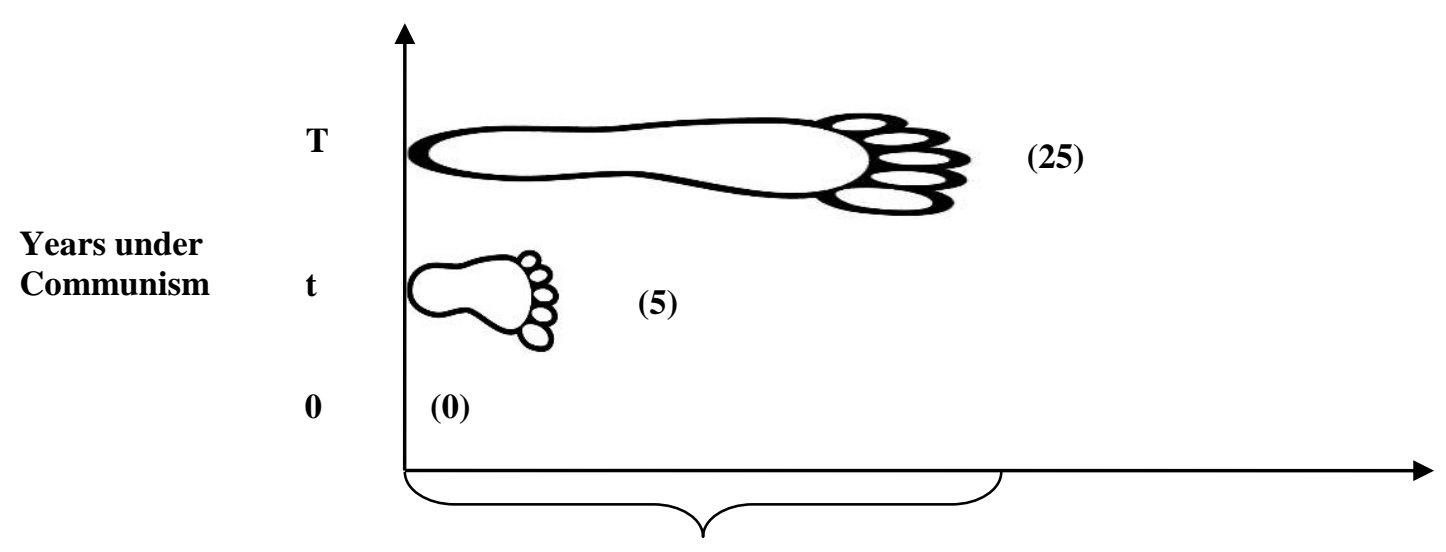

Communist Footprint (shorter/longer)

*NOTE: Our length of the communist footprint perspective treats individuals born during communism (cases $t$ and $\mathrm{T}$ ) differently by accounting for their number of years of exposure to the communist indoctrination: (e.g., 5 years vs. 25 years). Hence, this is a process perspective that involves different strengths of communist socialization and accumulation of fairness judgments against the communist regime. 
Figure 2a. The moderating effect of position level on the relationship between communist footprint and self-serving influence behavior

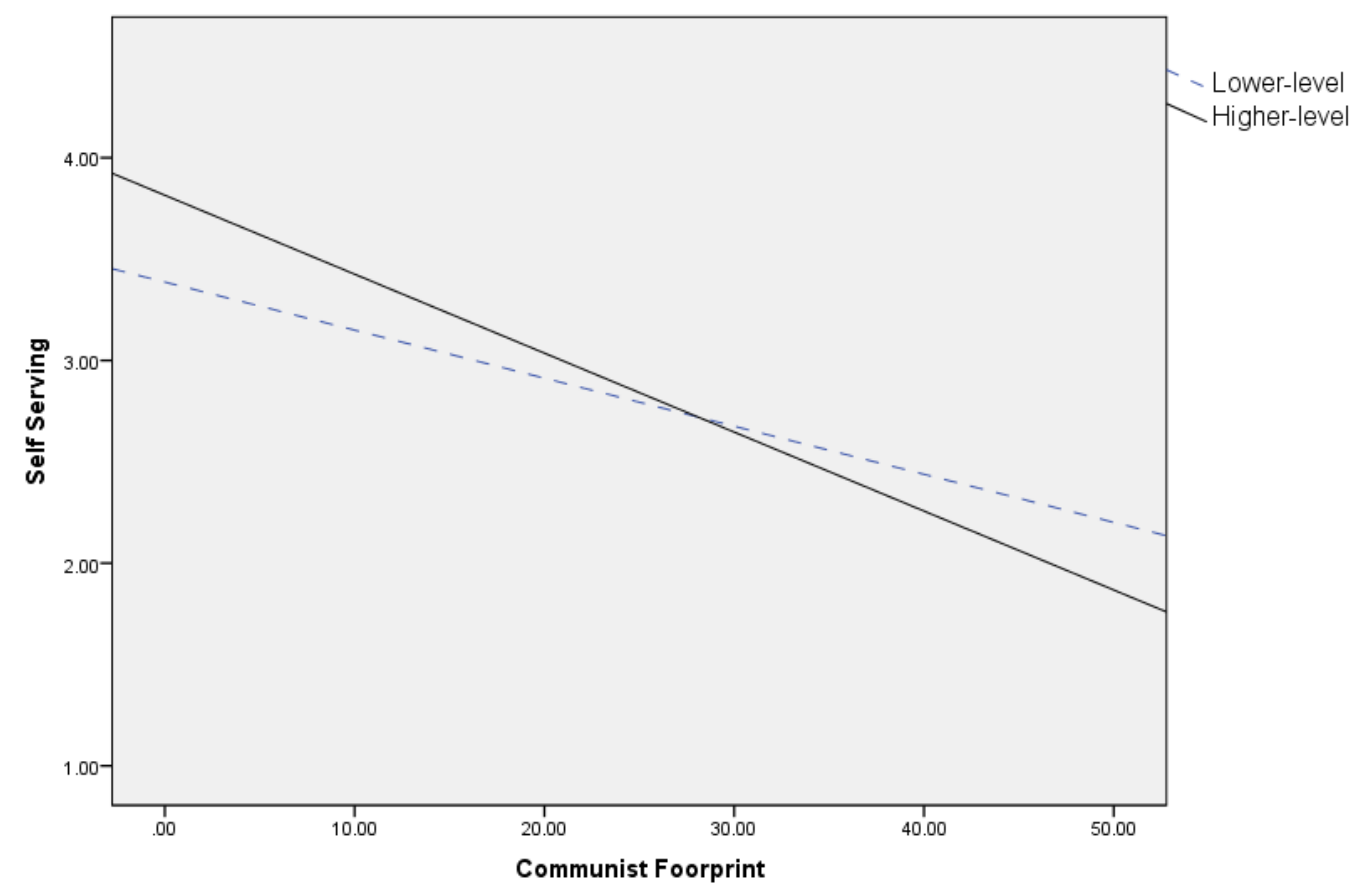

Figure $2 \mathrm{~b}$. The moderating effect of position level on the relationship between communist footprint and maliciously-intended influence behavior

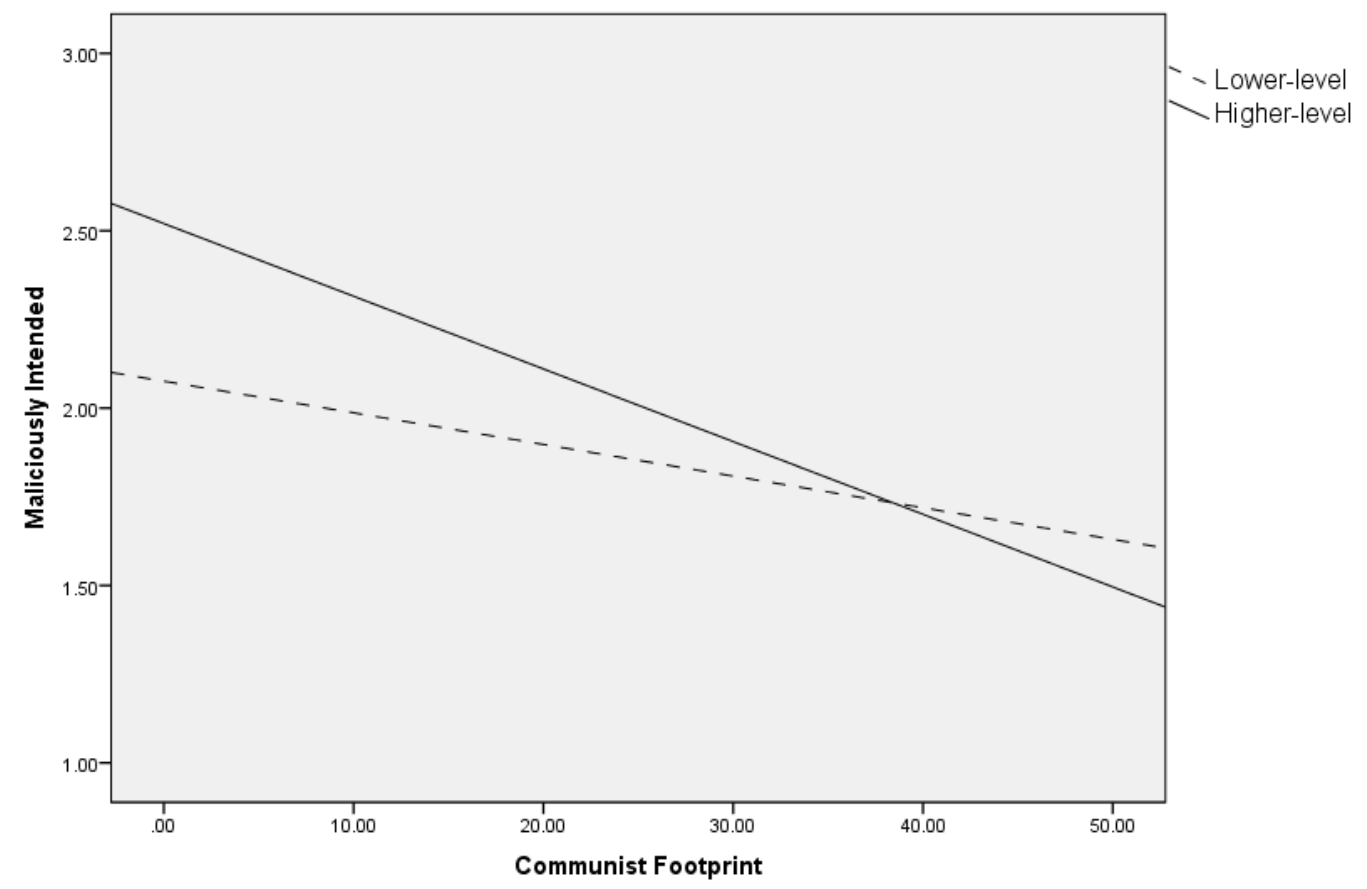


Table 1. Descriptive statistics and correlations

\begin{tabular}{|c|c|c|c|c|c|c|c|c|c|c|c|c|c|c|c|c|c|}
\hline & Variable & Mean & S.D. & 1 & 2 & 3 & 4 & 5 & 6 & 7 & 8 & 9 & 10 & 11 & 12 & 13 & 14 \\
\hline 1 & Pro-Organizational & 5.97 & 1.02 & 1 & & & & & & & & & & & & & \\
\hline 2 & Image Management & 4.64 & 1.26 & $.422 * *$ & 1 & & & & & & & & & & & & \\
\hline 3 & Self-Serving & 2.86 & 1.44 & -.022 & $.539 * *$ & 1 & & & & & & & & & & & \\
\hline 4 & Maliciously Intended & 1.93 & 1.12 & $-.132 * *$ & $.315^{* *}$ & $.658^{* *}$ & 1 & & & & & & & & & & \\
\hline 5 & Communist Footprint & 23.49 & 10.03 & $-.174 * *$ & $-.199 * *$ & $-.078^{* *}$ & -.037 & 1 & & & & & & & & & \\
\hline 6 & Reform Footprint & 12.53 & 1.01 & $.283 * *$ & $.246 * *$ & $-.196 * *$ & $-.214 * *$ & $.138 * *$ & 1 & & & & & & & & \\
\hline 7 & Gender & 1.53 & .499 & $.067^{*}$ & .045 & .022 & $-.096 * *$ & $-.133 * *$ & -.011 & 1 & & & & & & & \\
\hline 8 & Education & 3.94 & .986 & .034 & $.056^{*}$ & .051 & .035 & $.177 * *$ & -.028 & $-.179 * *$ & 1 & & & & & & \\
\hline 9 & Position Level & 2.10 & 1.13 & -.015 & -.039 & -.027 & -.007 & $.350 * *$ & -.027 & $-.314 * *$ & .423 & 1 & & & & & \\
\hline 10 & Company Size & 1.60 & .727 & $.141^{* *}$ & $.152 * *$ & $.158^{* *}$ & $.136^{* *}$ & .021 & $.231 * *$ & $-.066^{*}$ & $.130^{* *}$ & -.006 & 1 & & & & \\
\hline 11 & Company Industry & 5.47 & 2.78 & $-.067 *$ & $-.056^{*}$ & -.036 & -.044 & -.010 & $-.155^{* *}$ & $.141 * *$ & $.062 *$ & $-.081 * *$ & $-.149 * *$ & 1 & & & \\
\hline 12 & Current Economic Institutions & .618 & .072 & $-.250 * *$ & $-.287 * *$ & $-.325 * *$ & $-.293 * *$ & $.231 * *$ & $.666 * *$ & -.029 & $.065^{*}$ & .140 ** & $-.246 * *$ & .049 & 1 & & \\
\hline 13 & Prior Economic Institutions & 10.65 & 12.63 & -.038 & -.023 & .012 & $.083 * *$ & $.053^{*}$ & $-.410^{* *}$ & $-.073 * *$ & $.094 * *$ & $.275^{* * *}$ & -.041 & -.016 & $-.062 *$ & 1 & \\
\hline 14 & Current Political Institutions & 4.08 & 1.38 & -.022 & $-.106^{*}$ & $-.250 * *$ & $-.282 * *$ & -.025 & $.436 * *$ & $.092 * *$ & $-.122 * *$ & $-.119^{* *}$ & $.215^{* *}$ & .019 & $.714 * *$ & $-.318^{* *}$ & 1 \\
\hline 15 & Prior Political Institutions & -1.85 & 1.60 & $-.165^{* *}$ & $-.143^{* *}$ & $-.151^{* *}$ & $-.096^{* *}$ & $.221^{* *}$ & $.217 * *$ & $-.201 * *$ & $.404 * *$ & $.415^{* *}$ & -.039 & -.034 & $.549^{* *}$ & .376 & .052 \\
\hline
\end{tabular}


Table 2. Regression results

\begin{tabular}{|c|c|c|c|c|}
\hline & \multicolumn{2}{|c|}{$\begin{array}{l}\text { Organizationally Constructive } \\
\text { Influence Behaviors }\end{array}$} & \multicolumn{2}{|c|}{$\begin{array}{l}\text { Organizationally Destructive } \\
\text { Influence Behaviors }\end{array}$} \\
\hline & $\begin{array}{l}\text { Pro- } \\
\text { Organizational }\end{array}$ & $\begin{array}{l}\text { Image } \\
\text { Management }\end{array}$ & $\begin{array}{l}\text { Self- } \\
\text { Serving }\end{array}$ & $\begin{array}{l}\text { Maliciously } \\
\text { Intended }\end{array}$ \\
\hline \multicolumn{5}{|l|}{ Independent Variables } \\
\hline Communist Footprint & $\begin{array}{l}-.011 * * * \\
(.003)\end{array}$ & $\begin{array}{l}-.020 * * * \\
(.004)\end{array}$ & $\begin{array}{l}-.006 \\
(.004)\end{array}$ & $\begin{array}{l}.001 \\
(.003)\end{array}$ \\
\hline Position Level $*$ Communist Footprint & $\begin{array}{l}.002 \\
(.003)\end{array}$ & $\begin{array}{l}-.008 * * \\
(.003)\end{array}$ & $\begin{array}{l}-.015 * * * \\
(.004)\end{array}$ & $\begin{array}{l}-.006^{*} \\
(.003)\end{array}$ \\
\hline \multicolumn{5}{|l|}{ Control Variables } \\
\hline Position Level & $\begin{array}{l}.078 * * \\
(.030)\end{array}$ & $\begin{array}{l}.062^{\wedge} \\
(.035)\end{array}$ & $\begin{array}{l}.053 \\
(.044)\end{array}$ & $\begin{array}{l}-.016 \\
(.035)\end{array}$ \\
\hline Reform Footprint & $\begin{array}{l}.009 \\
(.197)\end{array}$ & $\begin{array}{l}.625 * * \\
(.243)\end{array}$ & $\begin{array}{l}.058 \\
(.298)\end{array}$ & $\begin{array}{l}-.619 * * \\
(.200)\end{array}$ \\
\hline Gender & $\begin{array}{l}.145^{* *} \\
(.055)\end{array}$ & $\begin{array}{l}.097 \\
(.068)\end{array}$ & $\begin{array}{l}.065 \\
(.080)\end{array}$ & $\begin{array}{l}-.238 * * * \\
(.063)\end{array}$ \\
\hline Education & $\begin{array}{l}.043 \\
(.031)\end{array}$ & $\begin{array}{l}.064 \\
(.041)\end{array}$ & $\begin{array}{l}.094 * \\
(.045)\end{array}$ & $\begin{array}{l}.046 \\
(.031)\end{array}$ \\
\hline Company Size & $\begin{array}{l}.112 * * \\
(.039)\end{array}$ & $\begin{array}{l}.130 * * \\
(.045)\end{array}$ & $\begin{array}{l}.148 * * \\
(.056)\end{array}$ & $\begin{array}{l}.078^{\wedge} \\
(.047)\end{array}$ \\
\hline Company Industry & $\begin{array}{l}-.007 \\
(.009)\end{array}$ & $\begin{array}{l}-.011 \\
(.012)\end{array}$ & $\begin{array}{l}-.012 \\
(.014)\end{array}$ & $\begin{array}{l}-.002 \\
(.010)\end{array}$ \\
\hline Current Economic Institutions & $\begin{array}{l}-1.40 \\
(3.46)\end{array}$ & $\begin{array}{l}4.59 \\
(4.61)\end{array}$ & $\begin{array}{l}-7.80 \\
(5.62)\end{array}$ & $\begin{array}{l}-13.18 * * * \\
(4.09)\end{array}$ \\
\hline Prior Economic Institutions & $\begin{array}{l}.000 \\
(.007)\end{array}$ & $\begin{array}{l}.021 * \\
(.009)\end{array}$ & $\begin{array}{l}-002 \\
(.011)\end{array}$ & $\begin{array}{l}-.017^{*} \\
(.007)\end{array}$ \\
\hline Current Political Institutions & $\begin{array}{l}.162 * \\
(.078)\end{array}$ & $\begin{array}{l}-.013 \\
(.097)\end{array}$ & $\begin{array}{l}.024 \\
(.122)\end{array}$ & $\begin{array}{l}.106 \\
(.098)\end{array}$ \\
\hline Prior Political Institutions & $\begin{array}{l}.152 \\
(.099)\end{array}$ & $\begin{array}{l}.412 * * * \\
(.123)\end{array}$ & $\begin{array}{l}-.060 \\
(.149)\end{array}$ & $\begin{array}{l}-.331 * * \\
(.103)\end{array}$ \\
\hline Survey Year & $\begin{array}{l}-.583 \\
(.537)\end{array}$ & $\begin{array}{l}-1.95 * * \\
(.694)\end{array}$ & $\begin{array}{l}.168 \\
(.846)\end{array}$ & $\begin{array}{l}-1.73^{* *} \\
(.584)\end{array}$ \\
\hline Intercept & $\begin{array}{l}1172.95 \\
(1072.22)\end{array}$ & $\begin{array}{l}3890.38^{* *} \\
(1385.54)\end{array}$ & $\begin{array}{l}-330.75 \\
(1687.50)\end{array}$ & $\begin{array}{l}-3437.35^{* *} \\
(1164.45)\end{array}$ \\
\hline Model F & $20.32 * * *$ & $19.04 * * *$ & $15.66 * * *$ & $14.02 * * *$ \\
\hline $\mathbf{R}^{2}$ & .165 & .156 & .132 & .120 \\
\hline Adjusted $\mathbf{R}^{2}$ & .157 & .148 & .124 & .112 \\
\hline Change $\mathbf{R}^{2}$ & .000 & $.004 *$ & $.011 * * *$ & $.003 *$ \\
\hline
\end{tabular}


APPENDIX 1. Description of the subordinate influence ethics (SIE) questionnaire

Pro-organizational influence behavior is typically prescribed and/or sanctioned by organizations for their subordinates. It uses strategies that tend to be directly beneficial to the organization, even if they are not directly beneficial for the individual. Examples include:

- $\quad$ demonstrate the ability to get the job done.

- $\quad$ help subordinates to develop their skills so that the subordinates, in turn, will be in a position to help them attain their objectives.

- $\quad$ behave in a manner that is seen as appropriate in the company.

- $\quad$ ask to be given the responsibility for an important project.

- maintain good working relationships with other employees, even if they dislike these other employees.

- $\quad$ work overtime, if necessary, to get the job done.

Image management influence behavior reflects the subtle actions that an individual may use to influence his/ her superiors to reach personal gain in addition to organizational gain. Examples include:

- $\quad$ volunteer for undesirable tasks to make themselves appreciated by the superior.

- $\quad$ learn the likes and dislikes of important people in the organization in order to avoid offending these people.

- $\quad$ identify and work for an influential superior who could help them get an advancement.

- $\quad$ attempt to act in a manner that they believe will result in others admiring them.

- $\quad$ use their technical expertise to make the superior dependent upon them.

Self-serving influence behavior shows self-interest being of paramount importance, and thus being above the interests of others and the organization. Whether it helps or harms the organization may be determined by the situation. Examples include:

- $\quad$ spread rumors about someone or something that stands in the way of their advancement.

- $\quad$ try to influence the boss to make a bad decision, if that decision would help them to get ahead.

- $\quad$ use their network of friends to discredit a person competing with them for a possible promotion.

- $\quad$ withhold information to make someone else look bad.

- $\quad$ take credit for a good job that was done by their subordinates.

- $\quad$ blame another for their own mistakes.

Maliciously intended influence behavior is used to directly and intentionally hurt others and/or the organization for personal gain. It is the extreme of the self-serving behavior, and in many industrialized countries, it would be considered illegal as it involves a "personal gain at all cost" attitude. Examples include:

- $\quad$ threaten to give valuable company information to someone outside the organization if their demands are not met.

- $\quad$ offer sexual favors to a superior.

- $\quad$ try to create a situation where a competitor for a promotion might be caught using illegal drugs or engaging in some other illegal activity.

- $\quad$ steal secret corporate documents and give them to another company in return for a better job at the other company.

- make anonymous, threatening phone calls to psychologically stress a competitor for a promotion.

Source: Adapted from Karam et al. (2013). 


\section{APPENDIX 2. Robustness tests}

First, we used HLM (Raudenbush and Bryk, 2002) to explore if possible cluster effects of individuals nested within countries may influence our results. We used the two-level HLM class of models as they "generate unbiased estimates of the fixed effects and their standard errors", where the fixed effects are our individual-level variables (Clarke, 2008: 756). HLM yields more conservative parameter estimates due to the partitioning of the variance, and hence is an even more rigorous test of our main findings (Clarke, 2008; Niehaus et al., 2014). We found that the intra-class correlations (the variance at the country level) were $20.82 \%, 16.69 \%, 11.43 \%$, and $12.85 \%$, respectively for each dependent variable. We estimated the means-as-outcomes model with grand-mean centered variables (Raudenbush and Bryk, 2002). As with our primary analyses, we found support for H1a (beta $=-0.011$, $\mathrm{p}<0.001$ ), H1b (beta $=-0.02, \mathrm{p}<0.001), \mathrm{H} 4 \mathrm{a}$ (beta $=-0.016, \mathrm{p}<0.001)$, and H4b (beta $=-0.005$, $\mathrm{p}<0.001)$. These results are in line with prior research noting that "when the proportion of variance explained at the group level is small, the estimates yielded using both methods [HLM and OLS] are very similar" (Niehaus et al., 2014: 102). Despite the smaller-than-recommended minimum group size of ten (we have 7 country groups), the results for the individual-level variables are not affected: "[t]he unbiased estimates of the fixed effect parameters might be obtained even for the extremely small samples. The structure of the sample (number of groups and group size) does not affect negatively the fixed effect estimates" (Laszkiewicz, 2013: 27), a conclusion supported for a minimum of 5 groups (Clarke, 2008).

Second, since the country dummies were entered into all our models but SPSS excluded them due to noted parameter redundancy, we thought it prudent to retest our models with an alternative approach to ensure that unobserved country heterogeneity does not influence our results (see Table A). We followed research advances in the finance literature that recommend demeaning all the variables (dependent, independent, and control) by subtracting their country means and estimating the transformed variables with OLS and robust standard errors to control for possible country heterogeneity (Gormley and Matsa, 2014). This procedure yields consistent estimates if there is possible unobserved group heterogeneity and is equivalent to the inclusion of individual group dummies (Gormley and Matsa, 2014). As with our primary analyses, we found support for $\mathrm{H} 1 \mathrm{a}, \mathrm{H} 1 \mathrm{~b}, \mathrm{H} 4 \mathrm{a}$, and $\mathrm{H} 4 \mathrm{~b}$ at conventional statistical levels.

Third, we retested our framework with the ratio of number of years spent under communism-toage, which captures the proportion of an individual's total life spent under communism, while also controlling for the subordinate's age via three groups for the early, mid, and late-career of the individual based on prior research equal to $0=24-38,1=29-53 ; 2=54-69$, respectively (see Table B) (Morison, Erickson, and Dychtwald, 2006). As with our primary analyses, we found support for H1a, H1b, H4a, and $\mathrm{H} 4 \mathrm{~b}$ at conventional statistical levels.

Fourth, to preclude the possibility that the results are influenced by collinearity among the variables, we excluded the Current Economic Institutions due to its high (0.714) correlation with Current Political Institutions. As with our primary analyses, we found support for H1a, H1b, H4a, and H4b at conventional statistical levels.

Fifth, since existing international management research has focused exclusively on the communist imprint and not the length of the communist footprint (e.g., Danis et al., 2011), we included the communist imprint in the same equation as the communist footprint. We believe this would provide an even more rigorous test of whether our proposed concept of the communist footprint affects subordinate influence behavior above and beyond the existing concept of the communist imprint. To obtain the communist imprint, we assigned 1 to individuals who entered the job market in or after the year of the start of reforms, and 0 to individuals who entered before the start of reforms (Danis et al., 2011). The communist footprint was as previously measured (individuals born after the start of market liberalization were coded as having 0 exposure to communism). After adding the communist imprint as an additional control, we continued finding support for $\mathrm{H} 1 \mathrm{a}, \mathrm{H} 2 \mathrm{a}, \mathrm{H} 4 \mathrm{a}$, and $\mathrm{H} 4 \mathrm{~b}$ at conventional statistical levels. We also found, as did Danis et al. (2011), that the communist imprint ultimately had no significant effect on any of the subordinate influence behavior. We conclude that prior research may have reached premature conclusions regarding how a communist exposure affects subordinates today. 
Table A. Robustness results with country demeaning of all variables to account for country heterogeneity

\begin{tabular}{|c|c|c|c|c|}
\hline & \multicolumn{2}{|c|}{$\begin{array}{c}\text { Organizationally Constructive } \\
\text { Influence Behaviors }\end{array}$} & \multicolumn{2}{|c|}{$\begin{array}{c}\text { Organizationally } \\
\text { Destructive Influence Behaviors }\end{array}$} \\
\hline & $\begin{array}{l}\text { Pro- } \\
\text { Organizational }\end{array}$ & $\begin{array}{c}\text { Image } \\
\text { Management }\end{array}$ & $\begin{array}{c}\text { Self- } \\
\text { Serving }\end{array}$ & $\begin{array}{l}\text { Maliciously } \\
\text { Intended }\end{array}$ \\
\hline \multicolumn{5}{|l|}{ Independent Variables } \\
\hline $\begin{array}{r}\text { Communist Footprint } \\
\text { Position Level * Communist Footprint }\end{array}$ & $\begin{array}{l}-.015 * * \\
(.006) \\
.002 \\
(.003)\end{array}$ & $\begin{array}{l}-.000 \\
(.007) \\
-.009 * * \\
(.003)\end{array}$ & $\begin{array}{l}.026 * * \\
(.008) \\
-.015 * * * \\
(.004)\end{array}$ & $\begin{array}{l}.010 \\
(.007) \\
-.005^{\wedge} \\
(.003)\end{array}$ \\
\hline \multicolumn{5}{|l|}{ Control Variables } \\
\hline $\begin{array}{r}\text { Position Level } \\
\text { Gender } \\
\text { Education } \\
\text { Company Size } \\
\text { Company Industry } \\
\text { Intercept }\end{array}$ & $\begin{array}{l}.038 \\
(.071) \\
.159 * * \\
(.058) \\
.059^{\wedge} \\
(.032) \\
.092^{*} \\
(.040) \\
.011 \\
(.010) \\
6.48^{* * *} \\
(.060) \\
\end{array}$ & $\begin{array}{l}.288^{* * *} \\
(.087) \\
.121^{\wedge} \\
(.071) \\
.049 \\
(.039) \\
.119^{*} \\
(.049) \\
. .014 \\
(.012) \\
5.34 * * * \\
(.072) \\
\end{array}$ & $\begin{array}{l}.395^{* * *} \\
(.099) \\
.070^{\wedge} \\
(.042) \\
.072^{\wedge} \\
(.043) \\
.138^{*} \\
(.055) \\
-.011 \\
(.014) \\
3.74 * * * \\
(.079) \\
\end{array}$ & $\begin{array}{l}.084 \\
(.081) \\
-.221 * * * \\
(.063) \\
.046 \\
(.029) \\
.072 \\
(.049) \\
-.003 \\
(.010) \\
2.56 * * * \\
(.072) \\
\end{array}$ \\
\hline Model F & $4.91 * * *$ & $6.07 * * *$ & $4.08 * * *$ & $2.90 * *$ \\
\hline $\begin{array}{l}\mathbf{R}^{2} \\
\text { Adjusted } \mathbf{R}^{2} \\
\text { Change } \mathbf{R}^{2}\end{array}$ & $\begin{array}{l}.024 \\
.019 \\
.000\end{array}$ & $\begin{array}{l}.030 \\
.025 \\
.006 * *\end{array}$ & $\begin{array}{l}.020 \\
.015 \\
.012 * * *\end{array}$ & $\begin{array}{l}.015 \\
.010 \\
.002^{\wedge}\end{array}$ \\
\hline
\end{tabular}

$\wedge \mathrm{p}<0.10 ; * \mathrm{p}<.05 ; * * \mathrm{p}<.01, * * * \mathrm{p}<0.001$. Presented are regression coefficients with robust standard errors in parentheses. This test follows Gormley and Matsa (2014) who recommend centering all variables (dependent, independent, and controls) around the country mean to account for unobserved country heterogeneity (equivalent to inclusion of country dummies). The country-level controls become constants and are dropped, leaving the company and individual-level variables for estimation. 
Table B. Robustness results including a control for age

\begin{tabular}{|c|c|c|c|c|}
\hline & \multicolumn{2}{|c|}{$\begin{array}{l}\text { Organizationally Constructive } \\
\text { Influence Behaviors }\end{array}$} & \multicolumn{2}{|c|}{$\begin{array}{l}\text { Organizationally Destructive } \\
\text { Influence Behaviors }\end{array}$} \\
\hline & $\begin{array}{c}\text { Pro- } \\
\text { Organizational }\end{array}$ & $\begin{array}{l}\text { Image } \\
\text { Management }\end{array}$ & $\begin{array}{c}\text { Self- } \\
\text { Serving }\end{array}$ & $\begin{array}{l}\text { Maliciously } \\
\text { Intended }\end{array}$ \\
\hline \multicolumn{5}{|l|}{ Independent Variables } \\
\hline Communist Footprint & $\begin{array}{l}-.1 .58 * * * \\
(.489)\end{array}$ & $\begin{array}{l}-2.27 * * * \\
(.625)\end{array}$ & $\begin{array}{l}-.710 \\
(.716)\end{array}$ & $\begin{array}{l}-.404 \\
(.523)\end{array}$ \\
\hline Position Level $*$ Footprint & $\begin{array}{l}-.005 \\
(.256)\end{array}$ & $\begin{array}{l}-.878 * * \\
(.311)\end{array}$ & $\begin{array}{l}-.1 .49 * * * \\
(.369)\end{array}$ & $\begin{array}{l}-.571^{*} \\
(.278)\end{array}$ \\
\hline \multicolumn{5}{|l|}{ Control Variables } \\
\hline Position Level & $\begin{array}{l}.088 * * \\
(.030)\end{array}$ & $\begin{array}{l}.074 * \\
(.036)\end{array}$ & $\begin{array}{l}.053 \\
(.045)\end{array}$ & $\begin{array}{l}-.012 \\
(.035)\end{array}$ \\
\hline Age & $\begin{array}{l}.097 \\
(.078)\end{array}$ & $\begin{array}{l}.033 \\
(.098)\end{array}$ & $\begin{array}{l}.020 \\
(.112)\end{array}$ & $\begin{array}{l}.068 \\
(.089)\end{array}$ \\
\hline Gender & $\begin{array}{l}.146^{* *} \\
(.055)\end{array}$ & $\begin{array}{l}.101 \\
(.068)\end{array}$ & $\begin{array}{l}.067 \\
(.080)\end{array}$ & $\begin{array}{l}-.237 * * * \\
(.063)\end{array}$ \\
\hline Education & $\begin{array}{l}.049 \\
(.039)\end{array}$ & $\begin{array}{l}.070^{\wedge} \\
(.040)\end{array}$ & $\begin{array}{l}.094 * \\
(.045)\end{array}$ & $\begin{array}{l}.047 \\
(.031)\end{array}$ \\
\hline Company Size & $\begin{array}{l}.114^{* *} \\
(.039)\end{array}$ & $\begin{array}{l}.070 \\
.131^{* *} \\
(.045)\end{array}$ & $\begin{array}{l}.141 * * \\
(.056)\end{array}$ & $\begin{array}{l}.076 \\
.078)\end{array}$ \\
\hline Company Industry & $\begin{array}{l}-.007 \\
(.009)\end{array}$ & $\begin{array}{l}-.010 \\
(.012)\end{array}$ & $\begin{array}{l}-.012 \\
(.013)\end{array}$ & $\begin{array}{l}-.002 \\
(.010)\end{array}$ \\
\hline Current Economic Institutions & $\begin{array}{l}-.962 \\
(1.88)\end{array}$ & $\begin{array}{l}-1.19 \\
(2.58)\end{array}$ & $\begin{array}{l}-.8 .44 * * \\
(3.12)\end{array}$ & $\begin{array}{l}-6.57 * * \\
(2.30)\end{array}$ \\
\hline Prior Economic Institutions & $\begin{array}{l}.001 \\
(.003)\end{array}$ & $\begin{array}{l}.005 \\
(.004)\end{array}$ & $\begin{array}{l}.000 \\
(.004)\end{array}$ & $\begin{array}{l}-.001 \\
(.003)\end{array}$ \\
\hline Current Political Institutions & $\begin{array}{l}.153 * * \\
(.057)\end{array}$ & $\begin{array}{l}.068 \\
(.070)\end{array}$ & $\begin{array}{l}.035 \\
(.089)\end{array}$ & $\begin{array}{l}.003 \\
(.073)\end{array}$ \\
\hline Prior Political Institutions & $\begin{array}{l}.170 * * * \\
(.034)\end{array}$ & $\begin{array}{l}.153 * * * \\
(.041)\end{array}$ & $\begin{array}{l}-.048 \\
(.047)\end{array}$ & $\begin{array}{l}-.009 \\
(.044)\end{array}$ \\
\hline Survey Year & $-.668 * * *$ & $-.642 * *$ & .221 & .216 \\
\hline Intercept & $\begin{array}{l}(.135) \\
1343.92 * * * \\
(268.77)\end{array}$ & $\begin{array}{l}(.191) \\
1290.10 * * \\
(381.86)\end{array}$ & $\begin{array}{l}(.225) \\
-436.15 \\
(449.06)\end{array}$ & $\begin{array}{l}(.164) \\
-426.32 \\
(327.30)\end{array}$ \\
\hline Model F & $19.15 * * *$ & $17.77 * * *$ & $14.46 * * *$ & $13.01 * * *$ \\
\hline & .167 & .157 & .132 & .120 \\
\hline Adjusted $\mathbf{R}^{2}$ & .158 & .148 & .122 & .111 \\
\hline Change $\mathbf{R}^{2}$ & .000 & $.005 * *$ & $.011 * * *$ & $.003 *$ \\
\hline
\end{tabular}

